\title{
17. PETROLOGY OF IGNEOUS ROCKS FROM LEG 22 IN THE NORTHEASTERN INDIAN OCEAN ${ }^{1}$
}

\author{
Roger Hekinian, Center Océanologique de Bretagne, Brest, France
}

\section{INTRODUCTION}

The petrology of the Indian Ocean floor is the least known of all the oceans. Most of the petrological data published from the floor of the Indian Ocean is limited to the mid-Indian oceanic ridges (M.I.O.R.) (Figure 1). Tholeiitic basalts are the most common types of rocks found on these ridges (Wiseman and Poole, 1937; Engel et al., 1965; Udintsev and Cherchysheva, 1965; Bezrukov et al., 1966; Hekinian, 1968). Unspecified types of basaltic rocks from the mid-Indian oceanic ridges were also described by Reinisch (1908), Korzhinskiy (1962), and by Gladkikh and Chernysheva (1966). Spilites, gabbros, anorthosites, serpentinites, and dunites were collected from fracture zones intersecting the mid-Indian oceanic ridge (Heezen and Nafe, 1964; Udintsev and Chernysheva, 1965; Chernysheva and Bezrukov, 1966; Cann and Vine, 1966; Hekinian, 1968; Engel and Fisher, 1969). Areas away from the mid-Indian oceanic ridges are relatively less known. Basaltic rocks and granites have been recovered from the Amirante Ridge (Wiseman and Poole, 1937; Bunce et al., 1966; Fisher et al., 1968). Sporadic basaltic outcrops have been described by Korzhinskiy (1962) and by Bezrukov et al., (1966) from the Ninetyeast Ridge. Pyroxenites, gabbros, and serpentinites were also reported (Hekinian, 1970) from the Ob Fracture Zone adjacent to Broken Ridge. Only two basaltic rocks have been described from seamounts located in the vicinity of the Indonesian arc. One consists of a porphyritic vesicular basalt collected near Christmas Island (Bezrukov et al., 1966) and the other of a vesicular basalt with alkaline affinities (Engel et al., 1965) from the Cocos Basin (Fig. 1).

During Leg 22 about 65 meters of basement rocks were recovered from seven drill sites (Figure 1, and Table 1). The volcanic sequences from the Ninetyeast aseismic ridge are quite different from the material found on the mid-Indian oceanic ridges. In order to comprehend the mode of emplacement and to speculate on the origin of Leg 22 material, a comparison with other volcanic provinces of the Indian Ocean has been made. These topographic provinces have been chosen in order to represent different tectonic settings, such as ridge-crests, islands associated with spreading ridges, isolated islands in an oceanic basin, and chains of islands associated with a subduction zone, such as the Indonesian Island arc.

\footnotetext{
${ }^{1}$ Contribution number 159 of the Departement Scientifique, Centre Oceánologique de Bretagne, B.P. 337-29273 Brest, France.
}

\section{ANALYTICAL METHODS}

Forty-nine chemical analyses of the major and minor elements were made by P. Cambon at the Centre Oceánologique de Bretagne using a Siemens X-ray fluorescence unit. Glassy discs were made with $1 \mathrm{~g}$ of calcinate samples mixed with $6 \mathrm{~g}$ of lithium tetraborate as the melting reagent and lanthanum oxide in order to eliminate the matrix effect. The percent of $\mathrm{FeO}$ was determined by the conventional wet method. The $\mathrm{Na}_{2} \mathrm{O}$ content was also determined by a Perkin Elmer atomic absorption unit.

Standard X-ray diffraction using a Co lamp and $\mathrm{Fe}$ filter was utilized to determine the fine fraction of the samples. The X-ray powder (Debby Sherrer) method was also used to determine individual minerals. The five axis universal stage was used to measure the $2 \mathrm{~V}$ of olivine and pyroxene and also to determine the anorthite content of the plagioclase.

\section{PETROLOGICAL DESCRIPTION}

A summary of the igneous rock descriptions from each site is shown in Figure 2. The modal analyses of some representative samples from different drill sites are shown in Table 3 . The chemistry and the norms are shown in Tables 4 through 9 . The location and the rock types at each site are listed in Table 1. The numbering system used to name the analyzed samples is shown in Table 2 .

\section{Site 211}

This site is located in the northeastern part of the Wharton Basin (Figure 1). Under a sediment cover of 401.5 meters, the drill penetrated a diabase sill ten meters thick. The upper contact of the sill was not recovered, and the bottom of the sill consists of about $15 \mathrm{~cm}$ of a weathered chilled margin (Figure 2). The chilled margin is in direct contact with a $3-\mathrm{cm}$-thick indurated (probably baked) sediment. The sediment below this contact zone consists of about 18 meters of soft variegated gray, cream and red nannofossil clay, and nannofossil ooze enriched in zeolite (Core 13, Section 1 and Core 14, Section 1). The lowest sediment occurs at 428.5 meters where it is in contact with the chilled margin of an amphibole-bearing basalt (Figure 2). The amphibole-bearing basalt consists of at least seven successive flows with chilled margins. These amphibolebearing basalts are interlayered with amphibolite flows.

\section{Diabase}

The name diabase is given to the rocks forming a sill comprising Core 12, Sections 1 and 2 . This unit consists of a phaneritic holocrystalline rock with ophitic and subophitic texture. The plagioclase $\left(\mathrm{An}_{40}-\mathrm{An}_{50}\right)$ occurs in 


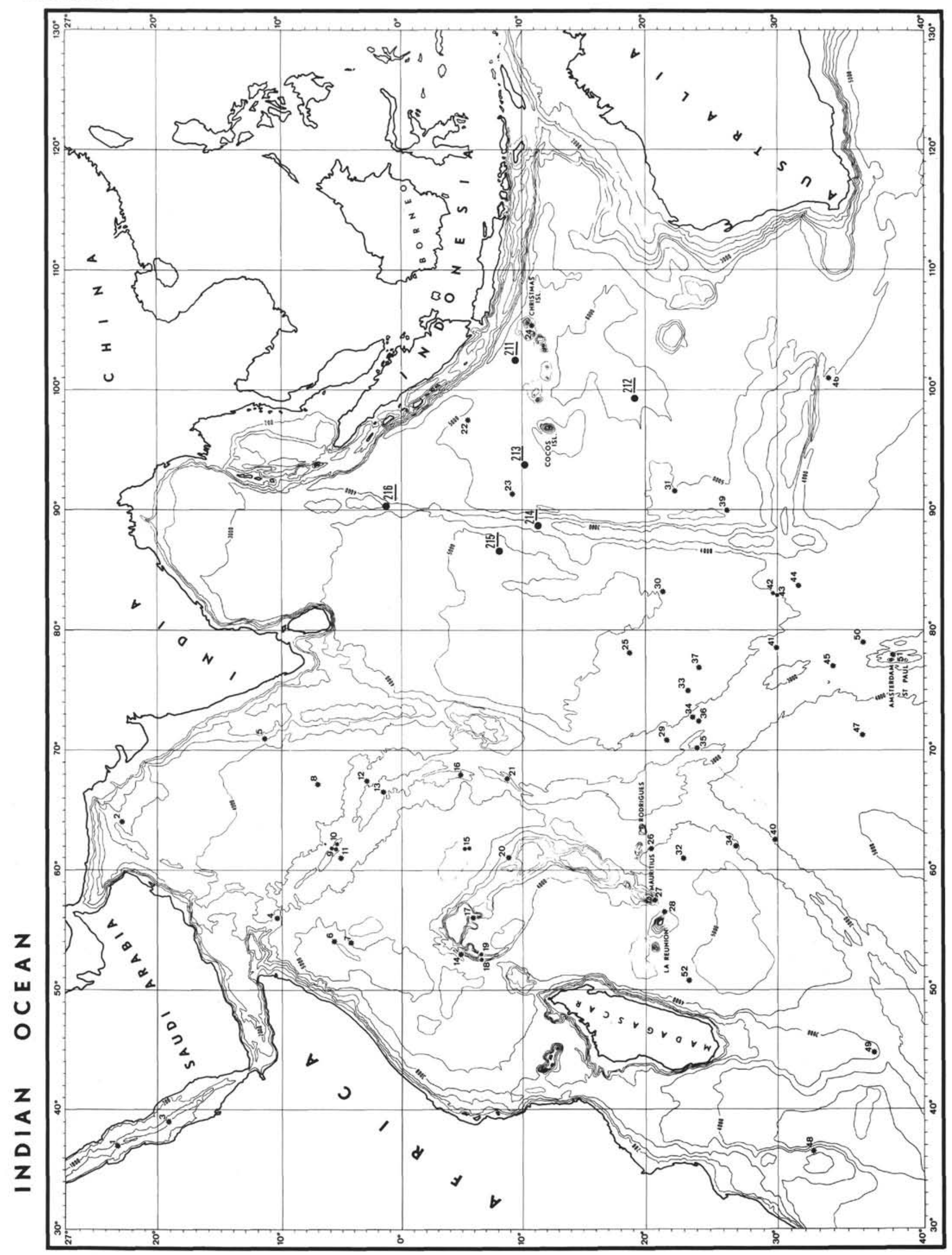


Figure 1. Physiographic map of the Indian Ocean after Belousov et al. (1962) showing the locations of the Glomar Challenger Sites 211, 212, 213, 214, 215, and 216. The numbers on the map refer to the location of rock samples published elsewhere: 1, 3, tholeiites (Schilling, 1969); 2, tuff, Spilite (Wiseman and Sewell, 1937); 4, limestone (Laughton, 1966); 5, 23, 24, 30, 31, 42, 44, basalt (Bezrukov et al., 1966); 6, 7, tholeiites and gabbro (Bunce et al., 1967); 8, 13, 14 basaltic rocks (Wiseman and Poole, 1937); 9, basalt, spilite, gabbro and ultramafic (Cann and Vine, 1966; Cann, 1969); 10, basalt and serpentinite (Chernysheva and Bezrukov, 1966); 11, basalt (Matthews, 1966); 12, spilite, 27 alkali-basalt, 25, 26, 28, 29, 37, 40, 41, 44, 49, tholeiites (Hekinian, 1968); 16, 32, 38, 45, basalt, dunite, gabbro and harzburgite, respectively (Udintsev and Chernysheva, 1965); 17, granite, 20, volcanics (Bunce et al., 1966); 18, 19, sandstone and basalt (Fisher et al., 1968); 21 ultramafics (Heezen and Nafe, 1964); 22, basalt, 33, 34, 35, 36 tholeiites (Engel et al., 1965); 46, gabbro, pyroxenite and serpentinite (Hekinian, 1970); 39, 47, basalts (Korzhinskiy, 1962; Gladkikh and Chernysheva, 1966). 
TABLE 1

Leg 22 Igneous Rocks

\begin{tabular}{|c|c|c|c|c|c|c|}
\hline Site & Latitude & Longitude & $\begin{array}{c}\text { Water } \\
\text { Depth } \\
\text { (Corr. m) }\end{array}$ & $\begin{array}{l}\text { Depth } \\
\text { Below } \\
\text { Sea } \\
\text { Floor } \\
\text { (m) }\end{array}$ & $\begin{array}{l}\text { Depth of } \\
\text { Penetra- } \\
\text { tion } \\
\text { (m) }\end{array}$ & Rock Types \\
\hline 211 & $09^{\circ} 46.53^{\prime} \mathrm{S}$ & $102^{\circ} 41.95^{\prime} \mathrm{E}$ & 5535 & 409 & 38 & $\begin{array}{l}\text { Diabase sill, } \\
\text { amphibolite, } \\
\text { basalt (with } \\
\text { amphiboles) }\end{array}$ \\
\hline 212 & $19^{\circ} 11.34^{\prime} \mathrm{S}$ & $99^{\circ} 17.84^{\prime} \mathrm{E}$ & 6243 & 516 & 5 & $\begin{array}{l}\text { Metabasalt } \\
\text { (pillow-lavas) }\end{array}$ \\
\hline 213 & $10^{\circ} 12.71^{\prime} \mathrm{S}$ & $93^{\circ} 53.77^{\prime} \mathrm{E}$ & 5611 & 154 & 21 & $\begin{array}{l}\text { Basalt } \\
\text { (pillow-lavas) }\end{array}$ \\
\hline 214 & $11^{\circ} 20.21^{\prime} \mathrm{S}$ & $88^{\circ} 43.08^{\prime} \mathrm{E}$ & 1665 & 440.5 & 55.7 & $\begin{array}{l}\text { Differentiated } \\
\text { rock, basalt }\end{array}$ \\
\hline 215 & $8^{\circ} 07.30^{\prime} \mathrm{S}$ & $86^{\circ} 47.50^{\prime} \mathrm{E}$ & 5319 & 151 & 25 & $\begin{array}{l}\text { Basalt } \\
\text { (pillow-lavas) }\end{array}$ \\
\hline 216 & $1^{\circ} 27.73^{\prime} \mathrm{N}$ & $90^{\circ} 12.48^{\prime} \mathrm{E}$ & 2247 & 457 & 27.5 & Basalt \\
\hline
\end{tabular}

prismatic and elongated laths usually greater than $1 \mathrm{~mm}$ in length. The main twinnings are according to the albite, carlsbad-albite, and pericline laws. Sometimes polysynthetic twinning occurs at the center of crystals without extension towards the margins. Zoned plagioclase with wavy extinction of the laths is commonly encountered. Some plagioclases are partially altered at their center; others have been completely replaced. The product of alteration consists of sericite, smectite, and chlorite. The clinopyroxene is a purplish titanaugite $\left(2 \mathrm{~V}=30^{\circ}-54^{\circ}\right)$ with good cleavage planes and parting. The pyroxene occurs in large plates (0.8-1.0 $\mathrm{mm}$ in diameter) often completely penetrated by plagioclase laths. The penetration of the plagioclase has sometimes separated the pyroxene into many individual grains which have conserved their optic continuity. Other grains are partially resorbed and show inclusions of magnetite and fibrous phyllosilicates. The opaques consist of magnetite and pyrite. The magnetite $(0.1-0.2 \mathrm{~mm}$ in diameter) usually occurs in anhedral grains and sometimes in elongated rods; it is often altered into a gray colored leucoxene and into a reddish purple hematite. The mica consists of a brown biotite and occurs in flakes which form reaction rims around the magnetite. Mixed-layer vermiculite-chlorite forms a minor constituent of the diabase sill and consists of radiating fibers which are pleochroic from yellowish green to green and have parallel extinction. Sometimes individual fibers of vermiculitechlorite surround flakes of biotite. Completely altered anhedral ferromagnesians, sometimes with olivine rims, occur throughout the sill. The replacement product of these crystals consists of calcite and serpentine. A few green amphibole flakes are present. Apatite needles occur as inclusions in the plagioclase laths.

The weathered chilled margin at the bottom of the sill displays a fine grained variolitic and intergranular texture. The plagioclase occurs as slender laths (0.5-1.6 mm length) oriented in a radiating fashion. Anhedral purplish titanaugite $(0.15 \mathrm{~mm}$ diameter $)$ occurs as interstitial material between plagioclase laths. The clinopyroxene is sometimes partially replaced by brown biotite and an iron oxide mineral. Olivine-outlined minerals completely replaced by calcite, brownish red aggregates of iron oxide, and serpentine also occur. The olivine-outlined minerals are more abundant at the chilled margin than in the upper part of the intrusive. Brown and green biotite also occur in the matrix. These biotites often show a reaction rim of yellowish brown fine aggregates, probably smectite or vermiculite. The interstices between the plagioclase laths are also filled by palagonite, amorphous iron oxide aggregates, and smectite. Veins of calcite and amorphous limonitic material occur.

The chemical analyses of four diabase sill rocks are shown in Table 4 . These rocks are characterized by a relatively low $\mathrm{SiO}_{2}$ content $(<46 \%)$, a high $\mathrm{K}_{2} \mathrm{O}$ content $(>1 \%)$, high $\mathrm{Na}_{2} \mathrm{O}$ content $(>3 \%)$, and a high $\mathrm{TiO}_{2}$ content $(>2 \%)$. These rocks are strongly alkaline with a $\mathrm{K}_{2} \mathrm{O} / \mathrm{Na}_{2} \mathrm{O}$ ratio $<1$. The high $\mathrm{H}_{2} \mathrm{O}$ content $(>3 \%)$ is primarily due to the presence of late hydrothermal alteration products such as chlorite, serpentine, and smectite. Other late stage crystallized minerals, biotite and hornblende, have also contributed to the increase in the $\mathrm{H}_{2} \mathrm{O}$ content of the rock. The lower contact zone of the sill has a higher $\mathrm{H}_{2} \mathrm{O}$ content of the rock $(>7 \%)$ than the interior of the sill. This high $\mathrm{H}_{2} \mathrm{O}$ content at the bottom of the sill is partly due to weathering. The chilled margin also differs from the rest of the sill by its relatively high $\mathrm{CaO}$ content (about $11 \%$ ), a higher $\mathrm{Fe}_{2} \mathrm{O}_{3} / \mathrm{FeO}$ ratio, and a lower $\mathrm{MgO}$ content (Table 4). The diabase is nepheline normative except for Sample $12-1,64-66 \mathrm{~cm}$ and has a normative olivine content varying between 5 and 19 percent (Table 2).

\section{Amphibolite}

This type of rock occurs in Core 14, Section 2 and Core 15, Sections 1 and 2 (Figure 2). The amphibolites are melanocratic and consist of different flows with chilled margins. At least four flows have been recognized. The chilled margins consist of aphanitic hypocrystalline rocks containing round light gray patches $(<1 \mathrm{~cm}$ in diameter) of 

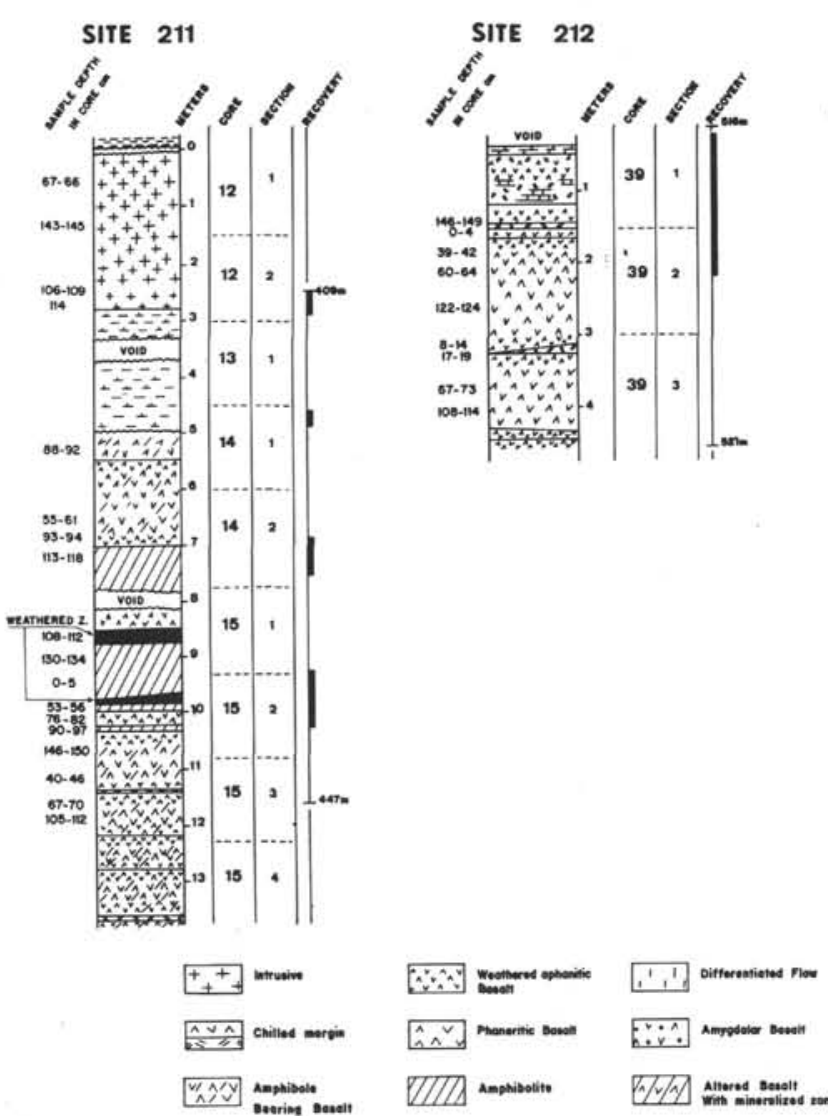

[ery

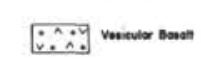
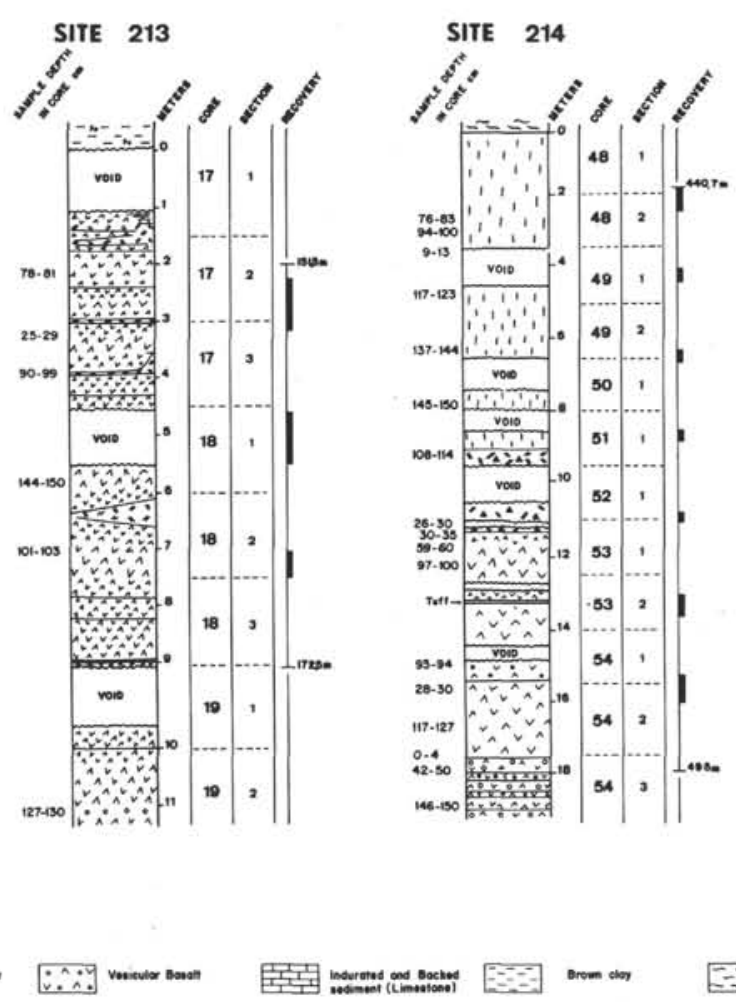

SITE 215

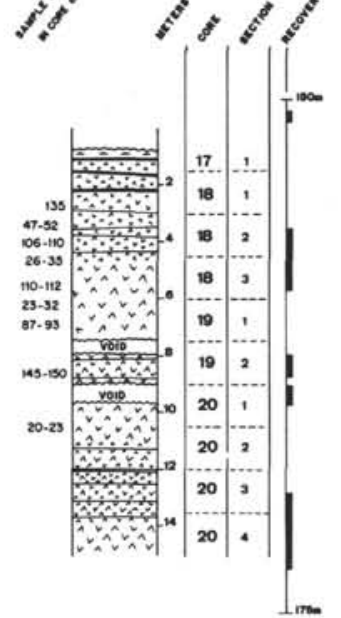

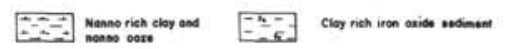

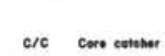

Figure 2. Schematic diagram of cores containing rocks recovered during Leg 22 of the Glomar Challenger in the northeastern Indian Ocean.

SITE 216
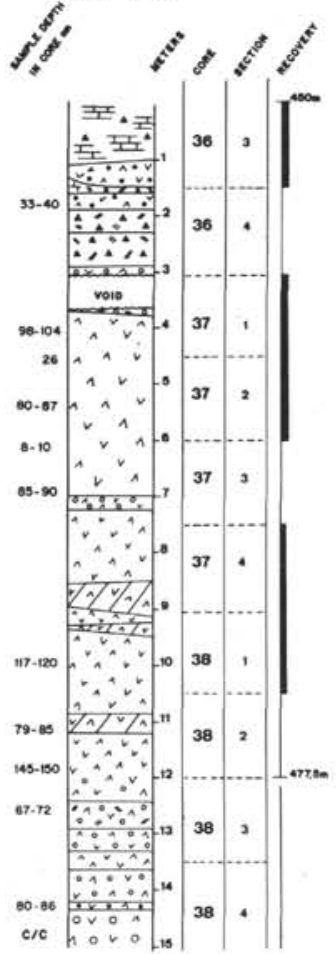
TABLE 2

Laboratory Numbers for Rock Samples from Leg 22

\begin{tabular}{|c|c|}
\hline Lab. No. & Sample \\
\hline $1 \mathrm{~S}^{\mathrm{a}}$ & $212-39-3,8-14$ \\
\hline $1 \mathrm{I}^{\mathrm{b}}$ & $212-39-3,8-14$ \\
\hline 2 & $212-39-3,8-14$ \\
\hline 3 & $212-39-3,67-73$ \\
\hline 4 & $212-39-2,0-4$ \\
\hline 5 & $212-39-2,39-42$ \\
\hline 6 & $212-39-2,60-64$ \\
\hline 7 & $211-15-2,0-5$ \\
\hline 8 & $211-15-2,76-82$ \\
\hline 9 & $211-12-2,114$ \\
\hline 10 & $211-12-1,64-66$ \\
\hline 11 & $211-12-1,143-145$ \\
\hline 12 & $211-12-2,106-109$ \\
\hline 13 & $211-15-1,130-134$ \\
\hline 15 & $212-39-1,146-148$ \\
\hline 16 & $212-39-2,122-124$ \\
\hline $17 \mathrm{~S}^{\mathrm{a}}$ & $212-39-3,108-114$ \\
\hline $17 \mathrm{I}^{\mathrm{b}}$ & $212-39-3,108-114$ \\
\hline 18 & $213-17-3,90-99$ \\
\hline 19 & $213-18-1,144-150$ \\
\hline 20 & $213-18-2,101-103$ \\
\hline 23 & $216-37-1,98-104$ \\
\hline 24 & $216-37-2,80$ \\
\hline 25 & $216-37-2,80-87$ \\
\hline 26 & $216-37-3,85-90$ \\
\hline 28 & $216-38-2,79-85$ \\
\hline 29 & $216-38-2,143-150$ \\
\hline 30 & $216-38, \mathrm{CC}$ \\
\hline 33 & $214-48-1,76-83$ \\
\hline 34 & $214-48-1,94-100$ \\
\hline 35 & $214-48-2,9-13$ \\
\hline 37 & $214-48-2,117-123$ \\
\hline 38 & $214-49-1,137-144$ \\
\hline 39 & $214-49-2,0-7$ \\
\hline 40 & $214-50-1,145-150$ \\
\hline 41 & $214-51-1,108-114$ \\
\hline 42 & $214-53-1,26-30$ \\
\hline 43 & $214-53-1,30-35$ \\
\hline 44 & $214-53-1,97-100$ \\
\hline 45 & $214-54-2,28-30$ \\
\hline 46 & $214-54-2,117-127$ \\
\hline 47 & $214-54-3,0-4$ \\
\hline 50 & $215-18-2,47-53$ \\
\hline 52 & $215-18-3,110-112$ \\
\hline 53 & $215-19-1,23-32$ \\
\hline 54 & $215-19-1,87-93$ \\
\hline 55 & $215-19-2,145-150$ \\
\hline 56 & $215-20-2,20-23$ \\
\hline 57 & $211-15-2,90-97$ \\
\hline
\end{tabular}

cryptocrystalline felsics and phyllosilicates. The patches are concentrated near the contact zones between the amphibolites in the basaltic rocks (Plate 1, Figure 1). Also, the patches contain incipient plagioclase, completely altered and resorbed olivine, chalcedony, and amphiboles. The inner parts of the flows are more crystalline and more coarse grained ( $0.4 \mathrm{~mm}$ in length), usually containing fresher olivine crystals. The matrix is chiefly composed of amphiboles and glass (Plate 2, Figure 1).

Two types of amphiboles were distinguished:

1) An oxyhornblende (0.1-0.4 mm in length) is the main constituent and occurs as radiating needles having arborescent or plumose forms. This amphibole $\left(2 \mathrm{~V}=52^{\circ}-64^{\circ}\right)$ is brown to dark brownish red and strongly pleochronic from yellowish brown to dark reddish brown. The extinction angle is $0^{\circ}-9^{\circ}$, but there is a preferentially parallel extinction.

2) The other type of amphibole (0.2-0.4 $\mathrm{mm}$ in length) is pale greenish yellow common hornblende with well developed cleavage planes. The common hornblende (2 $\mathrm{V}=72^{\circ} .80^{\circ}$ ) is pleochroic from pale yellowish green to greenish brown, has an extinction angle of $5^{\circ}-17^{\circ}$ and does not show crystallographic termination along its long axis.

The olivine $(0.3 \mathrm{~mm}$ in average diameter) occurs as euhedral crystals altered into iddingsite and replaced by calcite. Partially resorbed olivine $\left(2 \mathrm{~V}=77^{\circ}\right)$ is often rimmed by tiny elongated crystals of oxyhornblende. Calcite is also partially penetrated and included by both amphiboles. A few oxyhornblende crystals are surrounded by a greenish blue amphibole (ext. angle $\cong 20^{\circ}-25^{\circ}$ ). A few veins and veinlets of calcite also occur throughout the unit.

The chemical analyses and the norms of three amphibolites are shown in Table 4 . These rocks are characterized by a relatively low $\mathrm{SiO}_{2}$ content $(<43 \%)$ and a high $\mathrm{H}_{2} \mathrm{O}$ content $(>4 \%)$. The $\mathrm{TiO}_{2}$ and the $\mathrm{K}_{2} \mathrm{O}$ contents are fairly abundant $\left(>2 \%\right.$ and $>1 \%$, respectively). The $\mathrm{K}_{2} \mathrm{O} / \mathrm{Na}_{2} \mathrm{O}$ ratio of these rocks is less than $1 \%$, and the total iron content is less than $10 \%$ (Table 3 ). Two of these specimens contain nepheline in their norm while the third specimen (Core 15, Section 2, 0-5 cm) contains a small amount of hypersthene $(<2 \%)$ (Table 4$)$. The normative olivine content of the amphibolite varies between 7 and 16\% (Table 4).

\section{Amphibole Bearing Basalt}

This type of rock occurs in Core 14, sections 1 and 2 in Core 15, Sections 2, 3, and 4 and shows weathered aphanitic chilled margins. Crystallinity increases towards the inner part of each flow. The general textural feature is variolitic (Plate 2, Figure 2). The basalts contain felted aggregates of plagioclase microlites. The modal analyses of one specimen is shown in Table 3 . The plagioclase occurs in elongated thin rods (0.3-1.6 mm length) with a composition of $\mathrm{An}_{40}-\mathrm{An}_{60}$. In the least crystalline rocks, the plagioclase occurs as felted laths associated with a dark mesostasis. The olivine-outlined crystals (0.5-0.4 mm diameter) are altered by a reddish brown material, probably iddingsite. Sometimes they contain a core of calcite and serpentine. No fresh crystals of olivine were seen. Needles of brown mica (0.03-0.07 mm length) pleochroic from yellow green to reddish brown, uniaxial negative, and have parallel extinction, occur throughout the section. A few brown mica crystals occur as an alteration product of hornblende. Elsewhere, fresh hornblende occurs as greenish yellow elongated prisms which are pleochronic from greenish yellow to yellow brown and with a lower birefringence than brown mica. Greenish yellow common hornblende also occurs with traces of cleavage planes at $120^{\circ}$. Also observed were elongated rods of a reddish brown oxidized crystal which is probably hornblende. Both hornblende and mica sometimes occur surrounding calcite minerals in the matrix or even partially penetrating into the calcite. Large veins (up to $3 \mathrm{~mm}$ thick) of calcite were also noticed as well as sporadically distributed vesicles (about $3 \mathrm{~mm}$ in diamter), which occur throughout. Zeolite was found as an interstitial 
TABLE 3

Modal Analyses of Leg 22 Igneous Rocks

\begin{tabular}{|c|c|c|c|c|c|c|c|c|c|c|c|}
\hline \multirow{2}{*}{$\begin{array}{r}\text { Site } \\
\text { Core-Section } \\
\end{array}$} & \multicolumn{3}{|c|}{211} & \multirow{2}{*}{$\begin{array}{r}212 \\
39-3 \\
\end{array}$} & \multirow{2}{*}{$\begin{array}{l}213 \\
19-2 \\
\end{array}$} & \multicolumn{3}{|c|}{214} & \multirow{2}{*}{$\begin{array}{l}215 \\
19-1 \\
\end{array}$} & \multicolumn{2}{|c|}{216} \\
\hline & $12-1$ & $15-1$ & $15-3$ & & & $49-1$ & $53-1$ & $54-1$ & & $37-2$ & $37-4$ \\
\hline Depth in Core $(\mathrm{cm})$ & $90-93$ & $120-134$ & $67-70$ & $67-73$ & $127-130$ & $137-144$ & $97-100$ & $93-94$ & $87-93$ & $80-87$ & 145 \\
\hline Rock Types & Diabase & $\begin{array}{l}\text { Amphibo- } \\
\text { lite }\end{array}$ & $\begin{array}{l}\text { Amph. } \\
\text { Basalt }\end{array}$ & $\begin{array}{l}\text { Meta- } \\
\text { basalt }\end{array}$ & Basalt & $\begin{array}{c}\text { Differ- } \\
\text { entiated } \\
\text { Rocks }\end{array}$ & Basalt & $\begin{array}{l}\text { Ves. } \\
\text { Basalt }\end{array}$ & Basalt & $\begin{array}{l}\text { Patchy } \\
\text { Basalt }\end{array}$ & Basalt \\
\hline Plag. phncr. & & & & 3.71 & & 0.55 & & 0.20 & & & \\
\hline Plag. merphncr. & 41.12 & & 50.50 & 1.7 & & 4.71 & & 6.18 & 40.57 & & 1.18 \\
\hline Plag. matrix & & & & 38.86 & 46.40 & 39.34 & 33.00 & 41.04 & & 39.40 & 30.97 \\
\hline Clinopyroxene & 22.12 & & Tr. & 24.57 & 28.80 & 25.76 & 47.40 & 18.92 & 39.43 & 39.20 & 41.37 \\
\hline Fe-oxide min. & 6.21 & 0.28 & 5.28 & 5.14 & 7.60 & 7.20 & 10.20 & 7.57 & 10.57 & 11.60 & 12.29 \\
\hline Olivine & & 5.63 & & 4.29 & 11.80 & & & & 0.57 & & \\
\hline Mica & 8.72 & 3.09 & 0.22 & & Tr. & & & Tr. & & 1.6 & \\
\hline Calcite & & 3.81 & 8.04 & 2.00 & & 1.66 & & 7.17 & 0.86 & & \\
\hline Phyllosilicate $^{\mathrm{a}}$ & 21.81 & & & 5.82 & 5.4 & & 3.40 & 14.74 & 7.43 & 8.20 & 10.87 \\
\hline Hornblende & Tr. & 36.62 & 9.05 & & & & & & & & \\
\hline Oxyhornblende & & 43.09 & 9.30 & & & & & & & & \\
\hline Groundmass ${ }^{b}$ & & 8.45 & 15.58 & 14.28 & & 20.50 & 5.8 & 3.98 & & & 3.55 \\
\hline
\end{tabular}

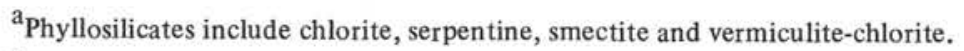

${ }^{\mathrm{b}}$ Groundmass includes glass, dark mesostasis and cryptocrystalline unidentified aggregates.

material between plagioclase laths and vesicles. Some of the vesicles show aggregates of K-Feldspar (staining method) at their edges. Rounded patches $(<1 \mathrm{~cm}$ diameter) of wellcrystallized material consisting of plagioclase laths, iron oxide, and olivine outlined minerals were observed near the contact zone with the amphibolite (Core 14, Section 2, $113-118 \mathrm{~cm}$ ). These patches are also surrounded by felted aggregates of mica.

One amphibole-bearing basalt has been chemically analyzed (Core 15, Section 2, 90-97 cm). This sample shows a higher $\mathrm{SiO}_{2}$ content $(47 \%)$ and $\mathrm{K}_{2} \mathrm{O}$ content $(>3 \%)$ than the diabase and the amphibolites associated at the same drill site. The $\mathrm{MgO}$ content $(<3 \%)$ is also lower than both the diabase sill and the amphibolite (Table 3 ). The amphibole-bearing basaltic rock is saturated and contains about $2 \%$ normative olivine and about $11 \%$ normative hypersthene (Table 4).

\section{Site 212}

This site is in the deepest part of the Wharton Basin (Figure 1). Igneous rocks were penetrated from 516.30 to 521 meters in Core 39, Sections 1, 2 and 3 (Figure 2). This unit is made up of a series of phaneritic zones grading towards aphanitic zones and altered chilled margins. The chilled margins ( $<2 \mathrm{~cm}$ thick) are light green and gray colored and represent glassy zones which have been altered by chlorite and smectite (Plate 3 ). A very few relics of dark gray basaltic glass, and veins of calcite and quartz occur at the margins. The succession of rock units is believed to represent several pillow-lavas with chilled margins. Seven pillow-lavas varying in thickness between 15 and $150 \mathrm{~cm}$ were counted (Figure 1). Indurated carbonates containing few fossils and angular rock fragments were observed at the top of Core 39 near the contact with the sediment (Plate $3)$. All the igneous rocks of Site 212 are altered; but since the inner zones of the pillows are better crystallized, they have been considered more appropriate for petrographic study.

The mineral constituents of the inner crystalline zones of the pillow-lavas consist of altered plagioclase phenocrysts (up to $3 \mathrm{~mm}$ in length), microphenocrysts $(0.06-1.0 \mathrm{~mm}$ in length), and matrix plagioclase ( $0.3 \mathrm{~mm}$ average length). The modal analyses of a sample from Site 212 is shown in Table 3. Due to the extensive alteration of these plagioclases, phenocrysts, and microlites, no conventional methods (universal stage or X ray) could be satisfactorily applied for the determination of their anorthite content. A few crystals show a clear rim which probably consists of sodic plagioclase (Plate 2, Figure 3). The altered product of the plagioclase consists of chlorite and smectite with $d$-spacings of $13.8 \AA$ which upon glycolation expand up to $16.5 d(\AA)$. Occasional pumpellyite, identified by the X-ray powder method, was also found as an alteration product of plagioclase. The pumpellyite has a low birefringence, wavy extinction, with bluish green to very pale green pleochroism, and is found in either radiating fibers or irregularly displayed at the center and the margins of the plagioclases. Olivine outlined phenocrysts are completely altered into a brown amorphous material and also into a golden yellow radiating vermiculite-smectite mixed layer mineral. The clinopyroxene is fresh, colorless, and has a $2 \mathrm{~V}$ of $56-60^{\circ}$ The size of the clinopyroxene does not exceed $0.3 \mathrm{~mm}$ in diameter. The groundmass consists of cryptocrystalline material, chlorite, smectite, and pumpellyite. A few vesicles $(0.2 \mathrm{~mm}$ in average diameter) filled with chlorite and 
TABLE 4

Chemical Analyses and Norms of Igneous Rocks, Site 211

\begin{tabular}{|c|c|c|c|c|c|c|c|c|}
\hline \multirow[b]{2}{*}{ Oxides } & \multicolumn{4}{|c|}{ Diabase Samples } & \multicolumn{3}{|c|}{ Amphibolite Samples } & \multirow{2}{*}{$\begin{array}{c}\begin{array}{c}\text { Basalt } \\
\text { Samples }\end{array} \\
57\end{array}$} \\
\hline & 9 & 10 & 11 & 12 & 7 & 8 & 13 & \\
\hline $\mathrm{SiO}_{2}$ & 42.92 & 45.86 & 43.24 & 40.77 & 40.95 & 42.56 & 38.01 & 47.23 \\
\hline $\mathrm{Al}_{2} \mathrm{O}_{3}$ & 14.63 & 15.07 & 14.27 & 14.28 & 16.54 & 16.85 & 17.60 & 16.89 \\
\hline $\mathrm{Fe}_{2} \mathrm{O}_{3}$ & 7.20 & 4.26 & 3.24 & 6.76 & 4.10 & 2.42 & 2.74 & 1.72 \\
\hline $\mathrm{FeO}$ & 3.15 & 6.60 & 7.30 & 2.32 & 5.00 & 6.97 & 7.20 & 7.44 \\
\hline $\mathrm{MgO}$ & 4.77 & 9.63 & 9.42 & 3.99 & 4.32 & 5.60 & 6.29 & 2.26 \\
\hline $\mathrm{CaO}$ & 10.51 & 5.83 & 5.70 & 11.37 & 8.75 & 7.87 & 8.50 & 6.53 \\
\hline $\mathrm{Na}_{2} \mathrm{O}$ & 3.37 & 3.20 & 3.58 & 3.40 & 3.24 & 4.00 & 2.78 & 3.60 \\
\hline $\mathrm{K}_{2} \mathrm{O}$ & 2.42 & 2.06 & 1.87 & 2.81 & 2.01 & 1.78 & 1.06 & 3.38 \\
\hline $\mathrm{TiO}_{2}$ & 2.24 & 2.29 & 2.21 & 2.17 & 2.51 & 2.53 & 2.79 & 2.62 \\
\hline $\mathrm{P}_{2} \mathrm{O}_{5}$ & 0.58 & 0.60 & 0.56 & 0.55 & 0.69 & 0.69 & 0.74 & 0.74 \\
\hline $\mathrm{CO}_{2}$ & 2.55 & 0.00 & 0.00 & 4.90 & 2.38 & 0.44 & 0.97 & 1.76 \\
\hline PF & 3.60 & 5.54 & 6.72 & 4.46 & 7.72 & 6.13 & 11.43 & 5.96 \\
\hline Total & 97.93 & 100.93 & 98.10 & 97.77 & 98.20 & 97.83 & 100.10 & 100.09 \\
\hline \multicolumn{9}{|l|}{ Norms } \\
\hline Q & 0.00 & 0.00 & 0.00 & 0.00 & 0.00 & 0.00 & 0.00 & 0.00 \\
\hline ne & 2.17 & 0.00 & 3.80 & 1.73 & 0.00 & 7.02 & 2.16 & 0.00 \\
\hline or & 14.30 & 12.17 & 11.05 & 16.60 & 11.87 & 10.51 & 6.26 & 19.97 \\
\hline$a b$ & 24.49 & 27.07 & 23.26 & 25.56 & 27.41 & 20.87 & 19.53 & 30.46 \\
\hline an & 17.64 & 20.67 & 17.34 & 15.40 & 23.85 & 22.76 & 31.19 & 16.43 \\
\hline (wo & 6.08 & 1.80 & 3.03 & 2.68 & 0.00 & 3.75 & 0.00 & 0.00 \\
\hline \multirow[t]{2}{*}{ di $\{$ en } & 5.26 & 1.35 & 2.13 & 2.31 & 0.00 & 2.38 & 0.00 & 0.00 \\
\hline & 0.00 & 0.27 & 0.64 & 0.00 & 0.00 & 1.13 & 0.00 & 0.00 \\
\hline \multirow{2}{*}{ hy $\left\{\begin{array}{l}\text { en } \\
\text { fs }\end{array}\right.$} & 0.00 & 2.19 & 0.00 & 0.00 & 1.53 & 0.00 & 0.00 & 4.47 \\
\hline & 0.00 & 0.44 & 0.00 & 0.00 & 0.23 & 0.00 & 0.00 & 6.28 \\
\hline fo & 4.63 & 14.31 & 14.94 & 5.33 & 6.46 & 8.10 & 10.97 & 0.81 \\
\hline fa & 0.00 & 3.17 & 4.96 & 0.00 & 1.09 & 4.24 & 4.90 & 1.25 \\
\hline $\mathrm{mt}$ & 3.66 & 6.17 & 4.69 & 1.18 & 5.94 & 3.50 & 3.97 & 2.49 \\
\hline ilm & 4.25 & 4.34 & 4.19 & 4.12 & 4.76 & 4.80 & 5.29 & 4.97 \\
\hline ap & 1.36 & 1.41 & 1.32 & 1.29 & 1.62 & 1.62 & 1.74 & 1.74 \\
\hline $\mathrm{rt}$ & 0.00 & 0.00 & 0.00 & 0.00 & 0.00 & 0.00 & 0.00 & 0.00 \\
\hline $\mathrm{hm}$ & 4.67 & 0.00 & 0.00 & 5.94 & 0.00 & 0.00 & 0.00 & 0.00 \\
\hline c & 0.00 & 0.00 & 0.00 & 0.00 & 0.29 & 0.00 & 0.44 & 1.25 \\
\hline $\mathrm{cc}$ & 5.80 & 0.00 & 0.00 & 11.14 & 5.41 & 1.00 & 2.20 & 4.00 \\
\hline C.I. & 33.63 & 38.13 & 35.89 & 25.74 & 30.46 & 36.00 & 42.17 & 17.69 \\
\hline D.I. & 40.97 & 39.25 & 38.12 & 43.90 & 39.29 & 38.42 & 27.95 & 50.43 \\
\hline
\end{tabular}

Note: $\mathrm{PF}=$ ignition; C.I. $=$ crystallization index;

D.I. $=$ differentiation index.

smectite occur. Veins and veinlets of calcite cross cut some of the pillow-lavas.

The chemical analyses and norms of the rocks sampled at different sections from Site 212 are shown in Table 5 . The rocks are characterized by a low $\mathrm{SiO}_{2}$ content $(<46 \%)$. Their $\mathrm{TiO}_{2}$ content is less than 1 percent. The presence of quartz and calcite veins indicates that solutions enriched in $\mathrm{Ca}$ and $\mathrm{Si}$ have been moved throughout the rock units.
These rocks are also characterized by a high $\mathrm{Fe}_{2} \mathrm{O}_{3} / \mathrm{FeO}$ ratio $(>1)$ accompanied by a high $\mathrm{H}_{2} \mathrm{O}$ content $(>4 \%)$. The high $\mathrm{K}_{2} \mathrm{O}$ content $(\geqslant 1 \%)$ reflects the presence of cryptocrystalline potassic feldspar (staining method) and smectite concentrated in the matrix of these rocks. Considerable variation in $\mathrm{CaO}$ and $\mathrm{H}_{2} \mathrm{O}$ occurs between the chilled altered margin (1.5\% and $19 \%$, respectively) and the inner crystalline zone of an analyzed core-margin pair (Table 5). 
TABLE 5

Chemical Analyses and Norms of Metabasalt Samples, Site 212

\begin{tabular}{|c|c|c|c|c|c|c|c|c|c|c|c|}
\hline & $1 \mathrm{~S}$ & 1I & 2 & 3 & 4 & 5 & 6 & 15 & 16 & $17 \mathrm{~S}$ & 71 \\
\hline & .06 & 43.81 & 6.16 & 44.08 & 46.40 & 44.93 & 45.30 & 44.97 & 45.66 & 39.25 & 43.64 \\
\hline $\mathrm{Al}_{2} \mathrm{O}_{3}$ & 33 & 16.39 & 16.01 & 15.57 & 17.85 & 15.62 & 16.83 & 15.91 & 16.14 & 14.59 & 16.68 \\
\hline $\mathrm{Fe}_{2} \mathrm{O}_{3}$ & 26 & 6.37 & 65 & 20 & .05 & 5.24 & 6.66 & 5.05 & .59 & .42 & 6.37 \\
\hline $\mathrm{FeO}$ & 52 & 2.53 & 3.00 & 3.36 & 2.34 & 3.39 & 3.00 & 3.00 & 3.11 & 3.00 & 2.31 \\
\hline & 96 & 7.63 & 8.24 & 7.94 & 5.40 & 7.03 & & 7.77 & 7.87 & 7.35 & 7.77 \\
\hline . & 1.50 & 8.00 & 7.63 & 11.55 & 7.56 & 12.73 & 9.24 & 3.50 & 8.68 & 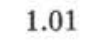 & 5.71 \\
\hline $\mathrm{Na}_{2} \mathrm{O}$ & 1.75 & 1.63 & 1.60 & 1.55 & 2.22 & 1.96 & $2: 24$ & 1.69 & 3.70 & 0.00 & .69 \\
\hline $\mathrm{K}_{2} \mathrm{O}$ & 3.09 & 2.54 & 2.91 & 1.65 & 2.06 & 0.98 & 1.30 & 5.14 & 2.34 & 3.00 & 3.46 \\
\hline $\mathrm{TiO}_{2}$ & 0.56 & 0.56 & 0.57 & 0.52 & 0.62 & 0.52 & 0.57 & 0.59 & 0.57 & 0.63 & 0.59 \\
\hline $\mathrm{P}^{2} \mathrm{O}_{5}$ & 0.02 & 0.08 & 0.12 & 0.09 & 0.10 & 0.09 & 0.09 & 0.09 & 0.11 & 0.03 & 0.05 \\
\hline $\mathrm{CO}_{2}$ & 0.00 & 1.60 & 0.17 & 2.70 & 0.00 & 2.30 & 0.23 & 1.00 & 0.97 & 0.00 & 1.23 \\
\hline PF & 18.97 & 8.08 & 7.29 & 5.48 & 7.75 & 4.63 & 6.40 & 0 & 33 & 18.77 & 7.89 \\
\hline Tot: & 9 & 99.2 & 99 & .77 & 4 & 1 & 9 & 0 & 06 & 5.04 & 97.35 \\
\hline \multicolumn{12}{|l|}{ Norms } \\
\hline Q & 8.01 & 0.68 & 0.00 & 1.30 & 2.54 & 1.77 & 0.12 & 0.00 & 0.00 & 14.73 & 0.25 \\
\hline ne & 0.00 & 0.00 & 0.00 & 0.00 & 0.00 & 0.0 & 0.00 & 0.00 & 5.51 & 0.00 & 0.00 \\
\hline or & 18.26 & 15.00 & 17.19 & 9.75 & 12.17 & 5.79 & 7.68 & 30.37 & 13.82 & 17.72 & 20.44 \\
\hline$a b$ & 14.80 & 13.79 & 13.53 & 13.11 & 18.78 & 16.58 & 18.95 & 14.30 & 21.13 & 0.00 & 14.30 \\
\hline an & 7.31 & 29.04 & 27.90 & 30.65 & 32.65 & 30.92 & 32.02 & 10.45 & 20.52 & 4.81 & 20.22 \\
\hline & 0.00 & 0.00 & 3.37 & 3.75 & 1.75 & 7.13 & 4.91 & 0.00 & 6.55 & 0.00 & 0.00 \\
\hline \multirow[t]{2}{*}{ di $\{$ en } & 0.00 & 0.00 & 2.91 & 3.12 & 1.51 & 5.90 & 4.24 & 0.00 & 62 & .00 & 0.00 \\
\hline & 0.00 & 0.00 & $0 \Omega 0$ & & & & & & 4 & & 0 \\
\hline & 14.84 & 19.00 & 8 & 16. & 3 & 0 & 8 & 1 & 00 & 30 & 5 \\
\hline & & $0 \Omega 0$ & 0.00 & 0.79 & 0.00 & 0.68 & 0.00 & 0.31 & 0.00 & 00 & .00 \\
\hline fo & 0 & 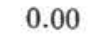 & J & 0.00 & 0.00 & 0 & 0.00 & 1.8 & 9.79 & 0.00 & 0.00 \\
\hline $\mathrm{fa}$ & 0.00 & 0.00 & 0.00 & 0.00 & 0.00 & 0.00 & 0.00 & 0.03 & 0.08 & 0.00 & 0.00 \\
\hline $\mathrm{mt}$ & 3.27 & 6.53 & 8.01 & 7.67 & 5.74 & 7.59 & 8.01 & 7.32 & 8.10 & 7.84 & 5.73 \\
\hline ilm & 1.06 & 1.06 & 1.08 & 0.98 & 1.17 & 0.98 & 1.08 & 1.12 & 1.08 & 1.19 & 1.12 \\
\hline ap & 0.04 & 0.18 & 0.28 & 0.21 & 0.23 & 0.21 & 0.21 & 0.21 & 0.25 & 0.07 & 0.11 \\
\hline $\mathrm{rt}$ & 0.00 & 0.00 & 0.00 & 0.00 & 0.00 & 0.00 & 0.00 & 0.00 & 0.00 & 0.00 & 0.00 \\
\hline $\mathrm{hm}$ & 5.60 & 1.86 & 0.12 & 0.00 & 3.08 & 0.00 & 1.13 & 0.00 & 0.00 & 2.01 & 2.41 \\
\hline c & 6.12 & 0.31 & 0.00 & 0.00 & 0.00 & 0.00 & 0.00 & 3.73 & 0.00 & 9.57 & 2.74 \\
\hline S & 0.00 & 3.63 & 0.38 & 6.14 & 0.00 & 5.23 & 0.52 & 2.27 & 2.20 & 0.00 & 2.79 \\
\hline 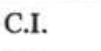 & 80 & 30.50 & 30.11 & 39.08 & 37.12 & 44.83 & 42.51 & 15.71 & 42.40 & 6.66 & 22.17 \\
\hline D.I. & 41.08 & 29.49 & 30.73 & 24.17 & 33.50 & 24.15 & 26.76 & 44.67 & 40.47 & 32.46 & 34.99 \\
\hline
\end{tabular}

Note: $\mathrm{PF}=$ ignition ; .I. $=$ crystallization index D.I. $=$ differentiation index.

The $\mathrm{TiO}_{2}$ content $(0.56 \%)$ is the same within the two zones (Table 5). It is likely that weathering by seawater has been partially responsible for the alteration of these rocks.

Weathering is characterized by the presence of some palagonite veins at the margins of the pillow-lavas and by the presence of amorphous limonite. However, the presence of pumpellyite and chlorite indicate burial metamorphism (Coombs et al., 1960; Winkler, 1967) as the former is characteristic of the pumpellyite-prehnite-quartz facies. For purposes of comparison with other altered and fresh rocks from other oceanic provinces, the variation diagrams $\mathrm{H}_{2} \mathrm{O}-\mathrm{CaO}-\mathrm{Na}_{2} \mathrm{O}$ are shown in Figures 3 and 4 . These figures show the plots for the mid-Indian oceanic ridge fresh and weathered (by seawater) basalts together with other altered (metamorphosed) rocks from the Carlsberg Ridge (Cann, 1969) and from the North Atlantic Ocean (Melson and Van Andel, 1966). These fresh and weathered basalts from the M.I.O.R. contain less than $4 \% \mathrm{H}_{2} \mathrm{O}$, their $\mathrm{CaO}$ content varies between 10 and $14 \%$, and their $\mathrm{Na}_{2} \mathrm{O}$ values are comprised between 2 and $4 \%$. The spilites from the Carlsberg Ridge (Cann, 1969), the greenstones from the Atlantic Ocean (Melson and Van Andel, 1966) and the rocks from the Wharton Basin (Site 212) have a $\mathrm{H}_{2} \mathrm{O}$ content higher than $2 \%$, variable $\mathrm{CaO}$ contents $(2-13 \%)$, and variable $\mathrm{Na}_{2} \mathrm{O}$ contents $(1-6 \%)$. It is known that severe weathering could give rise to the depletion of $\mathrm{CaO}$ and 


\section{R. HEKINIAN}

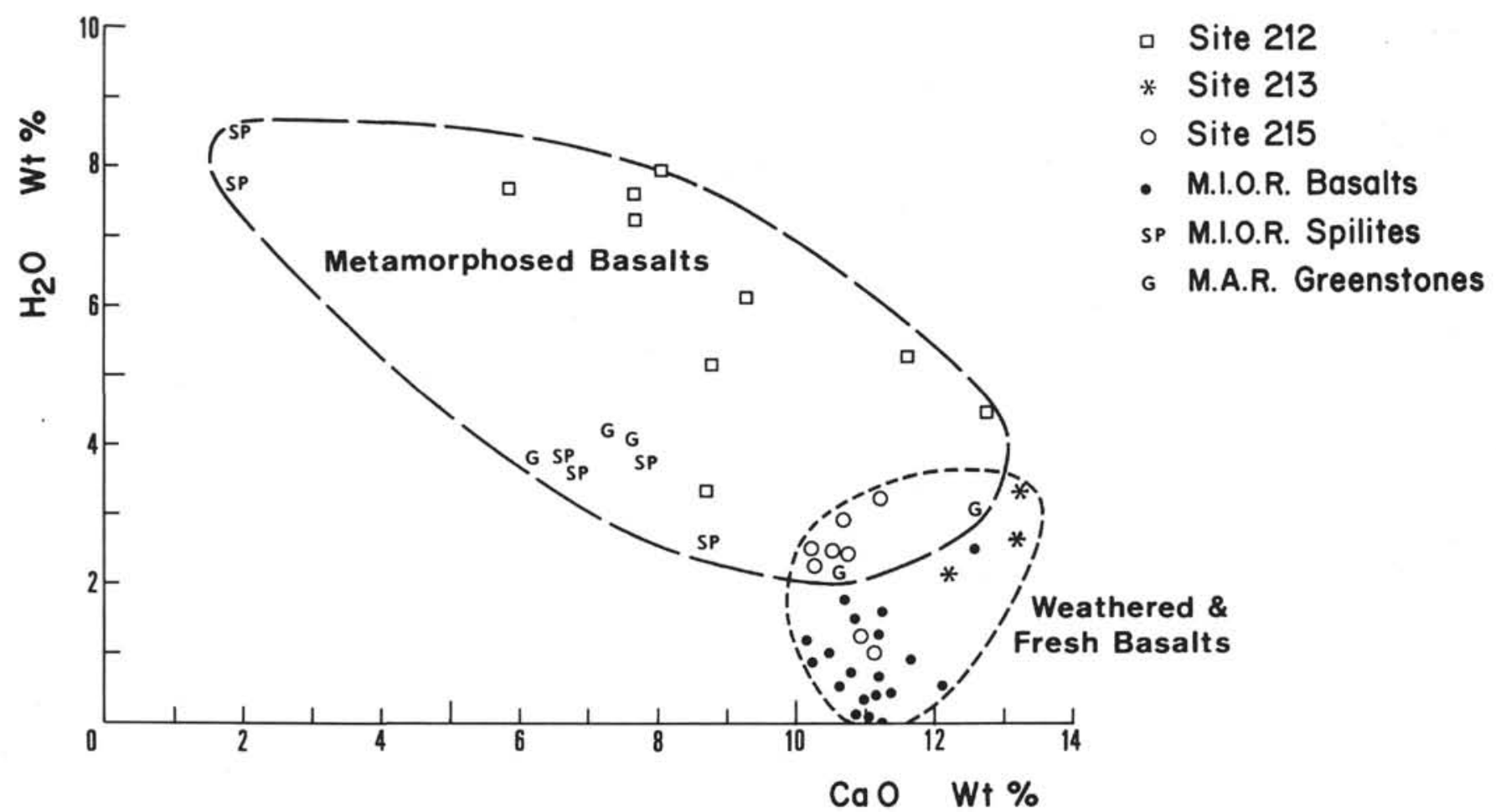

Figure 3. $\mathrm{H}_{2} \mathrm{O}-\mathrm{CaO}$ variation diagram of altered rocks from the Mid-Atlantic Ridge (Melson and van Andel, 1966; Bonatti et al., 1971) and from the mid-Indian oceanic ridge (Wiseman and Sewell, 1937; Cann, 1969). The weathered and fresh basalts are confined to the mid-Indian oceanic ridge (Engel et al., 1965; Bezrukov et al., 1966; Hekinian, 1968; Cann, 1969). Sites 213 and 215 are the location of the Indian Ocean floor basalts and Site 212 is the location of the metabasalts from the Wharton Basin.

$\mathrm{Na}_{2} \mathrm{O}$ (Aumento et al., 1971). The extreme variability of the $\mathrm{CaO}$ and $\mathrm{Na}_{2} \mathrm{O}$ contents of the rocks from Site 212 corresponds to the concentration of pumpellyite and calcite. Usually, low $\mathrm{Na}_{2} \mathrm{O}$ and $\mathrm{SiO}_{2}$ contents characterize the specimens (Site 212) enriched in pumpellyite. The rocks from Site 212 are depleted in their $\mathrm{TiO}_{2}$ content $(<1 \%)$ with respect to the spilites and the greenstones from elsewhere (Cann, 1969; Melson and Van Andel, 1966). The name "metabasalt" has been given to the rocks of Site 212 because there are two types of alterations, which make a more precise classification difficult.

\section{Site 213}

Site 213 was drilled in the western part of the Wharton Basin near the Ninetyeast Ridge. The basement rocks were penetrated at about 152 meters and consist of a light brown (5 Y R 5/6) weathered and light olive gray (5 Y 6/1) partially weathered sequence of pillow-lavas. At least 11 successive pillow-lavas with upper and lower chilled margins were recognized (Figure 2). The glassy margin of the uppermost pillow-lava is in direct contact with indurated nannofossil ooze (Figure 2). Fresh basaltic glass coated and veined by palagonite occurs at the lower and upper chilled margin of each pillow-lava. Sometimes a thin film of manganese was seen coating the chilled margins of the upper pillow-lavas. Veins of calcite occur throughout this unit.
The pillow-lavas from Site 213 vary in size between 50 $\mathrm{cm}$ to $150 \mathrm{~cm}$ in thickness and contain three texturally different zones as follows:

1) The outer zone is a glassy weathered margin containing brownish yellow aggregates of smectite with reddish brown amorphous limonite and fresh glass. Most of the specimens show that the ferromagnesian minerals and the glass have been completely weathered. The plagioclases are the only minerals still recognizable. However, most of the large plagioclase (1.0-1.6 mm length) have been replaced by calcite while the matrix plagioclase $(0.3 \mathrm{~mm}$ average length) is fresh or only partially replaced by calcite. Round and oval reddish brown patches enriched in iron oxide material was noticed in one specimen (Core 17, Section 3, 90-93 $\mathrm{cm})$.

2) The intermediate zone of the pillow-lava is a finegrained, hypocrystalline, transitional, weathered zone. Often, agglomerations of plagioclase phenocrysts are set in a groundmass composed of a dark mesostasis containing plagioclase microlites and small amounts of clinopyroxene granules, palagonites, and reddish brown amorphous material. Only a few vesicles $(<0.3 \mathrm{~mm}$ in diameter) filled with palagonite were observed.

3) The inner zone is crystalline and fresher than the two outer ones and contains agglomerations of plagioclase phenocrysts (1.6-4.8 mm in length) and microphenocrysts (0.6-1.6 $\mathrm{mm}$ in length; see Plate 2, Figure 4). Modal 


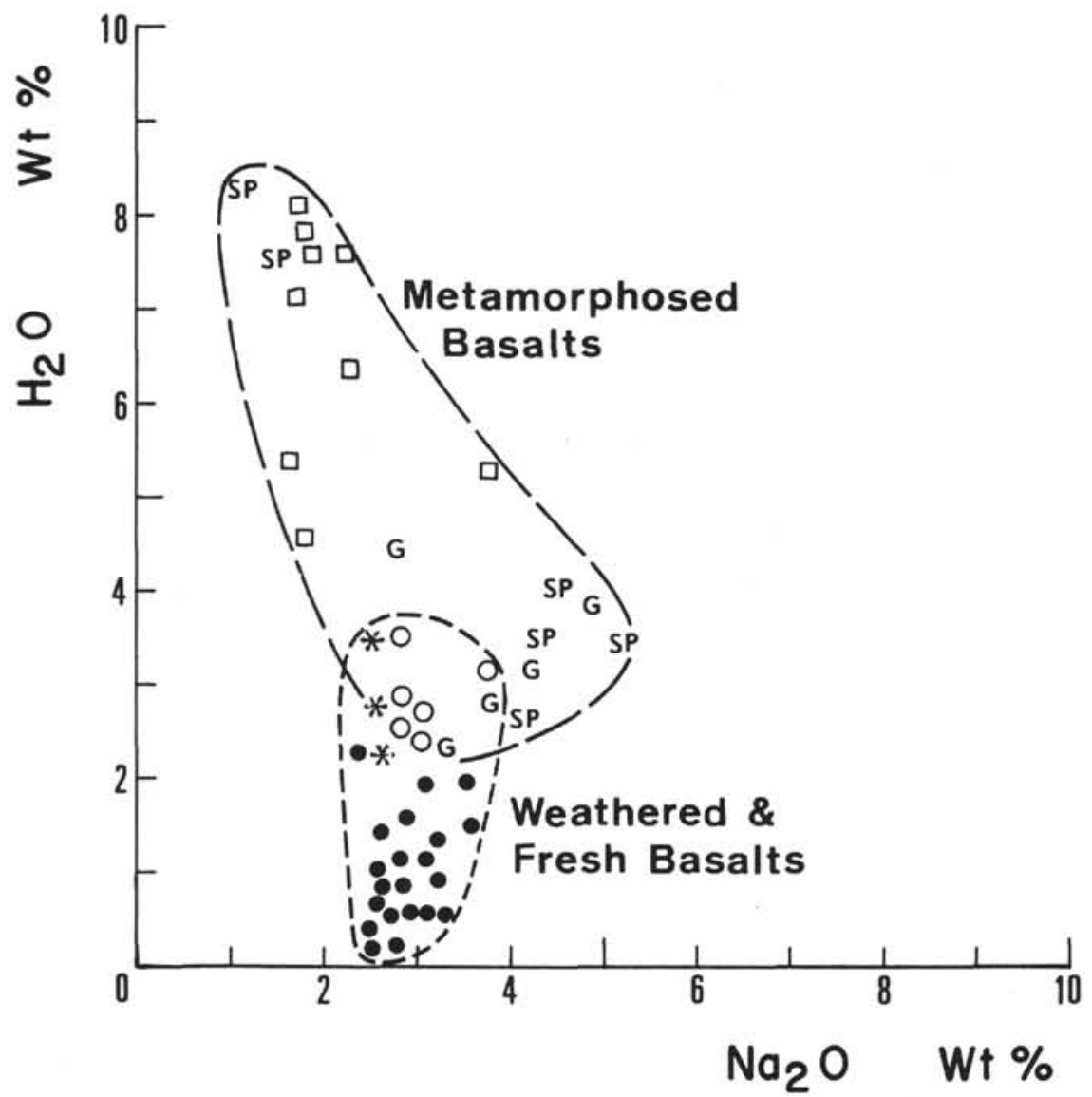

- Site 212

* Site 213

- Site 215

- M.I.O.R. Basalts

SP

M.I.O.R. Spilites

G M.A.R. Greenstones

Figure 4. $\mathrm{H}_{2} \mathrm{O}-\mathrm{Na} \mathrm{N}_{2} \mathrm{O}$ variation diagram shows the plot of the altered samples from the Indian floor and from the mid-oceanic ridges of the Atlantic and the Indian oceans. The symbols and references are the same as in Figure 3.

analyses of a sample from this zone is shown in Table 3. The anorthite values of these plagioclases vary between $A n_{51}$ and $A n_{61}$. Some of the plagioclase are replaced at their center by calcite. The groundmass is hypocrystalline with small amounts of palagonite and abundant plagioclase laths ( $<0.6 \mathrm{~mm}$ in length). The plagioclase of the matrix has a fan-shaped form, and elongated rods are seen to penetrate the clinopyroxene. The clinopyroxene (2 $\mathrm{V}=45^{\circ}-49^{\circ}$ ) is colorless to very pale green augite and varies in size from 0.05 to $1.6 \mathrm{~mm}$ in diameter. The clinopyroxene sometimes contains inclusions of iron oxide minerals. Olivine outlined crystals (0.1-1.3 mm in diameter) are completely replaced by iddingsite, serpentine, and iron oxide minerals. Serpentine and smectite were also detected between the interstices of the plagioclase laths. Traces of brown mica were observed as reaction rims around opaques. Vesicles (0.08-0.4 $\mathrm{mm}$ in diameter) filled with palagonite are scattered throughout the rocks. However, there are also larger vesicles $(>1 \mathrm{~cm}$ in diameter) in the interior of a pillow near the bottom of Section 2, Core 19 (Figure 2).

The chemical analyses of three partially weathered basalts from Site 213 are shown in Table 6. The weathering of these rocks is reflected in their relatively high $\mathrm{Fe}_{2} \mathrm{O}_{3}$ / $\mathrm{FeO}$ ratio $(>1)$ and $\mathrm{H}_{2} \mathrm{O}$ content higher than $2 \%$. They also have a high $\mathrm{Al}_{2} \mathrm{O}_{3}$ and $\mathrm{CaO}$ content $(>17 \%$ and about $13 \%$, respectively). The $\mathrm{K}_{2} \mathrm{O}$ content varies between 0.3 and $1 \%$ (Table 6 ). The normative calculation of these basalts does not reflect the presence of altered modal olivine. Instead, the depletion of the $\mathrm{MgO}$ content due to its leaching into seawater has enhanced the normative percentage of ilmenite and magnetite.

\section{Site 214}

This site, drilled on the Ninetyeast Ridge, commences with aphanitic medium dark gray (N4) rocks recovered at 440.5 meters under the sea floor and ending at 468.2 meters (Figure 2). The low part of this aphanitic flow is in contact with a tuffaceous sediment (Figure 2). The tuff consists of dark gray angular rock fragments $(\simeq 10 \%)$ mixed with about $55 \%$ sand-size $(<0.7 \mathrm{~mm}$ diameter) angular crystals of plagioclase, clinopyroxene, calcite, titanomagnetite iron sulfate minerals, and glass. Many of the coarse and the fine (clay, silt) fractions (about 35\%) consist of pyrite and chalcopyrite. The tuffaceous layer is light olive gray (5 Y 5/2) and occurs at 468.2-486.1 meters depth. At 486.1 meters, the tuff is in contact with a dark gray (N3) basalt flow having an upper and a lower fine-grained chilled margin. The lower contact is with a thin dusky blue green (5 BG 3/2) tuffaceous sediment (487.9-488.1 meters) made up of about $50 \%$ sand containing plagioclase (0.15 mm-0.04 mm length), clinopyroxene, chlorite flakes, and iron oxide minerals. The clay and silt size fraction (43\%) is made up mostly of plagioclase and pyroxene. About $7 \%$ of semi-indurated pellets of tuff was seen at 488.1 meters. Under the tuffs, there is another dark gray basaltic layer (Core 54, Sections 1 and 2) similar 
TABLE 6

Chemical Analyses and Norms of Basalt Samples from Sites 213 and 215

\begin{tabular}{|c|c|c|c|c|c|c|c|c|c|}
\hline & 18 & 19 & 20 & 55 & 56 & 50 & 52 & 53 & 54 \\
\hline $\mathrm{SiO}_{2}$ & 45.58 & 45.63 & 48.54 & 49.12 & 48.29 & 47.45 & 49.68 & 50.23 & 48.92 \\
\hline $\mathrm{Al}_{2} \mathrm{O}_{3}$ & 17.76 & 17.18 & 17.48 & 16.06 & 16.21 & 16.29 & 16.51 & 16.58 & 16.53 \\
\hline $\mathrm{Fe}_{2} \mathrm{O}_{3}$ & 7.66 & 7.57 & 5.81 & 3.90 & 2.54 & 4.84 & 2.59 & 2.72 & 2.46 \\
\hline $\mathrm{FeO}$ & 3.20 & 3.00 & 4.73 & 5.00 & 5.77 & 3.98 & 5.63 & 5.69 & 5.92 \\
\hline $\mathrm{MgO}$ & 3.05 & 5.40 & 5.14 & 5.93 & 6.48 & 5.93 & 6.82 & 6.47 & 6.15 \\
\hline $\mathrm{CaO}$ & 13.32 & 13.34 & 12.30 & 11.28 & 10.24 & 10.81 & 10.52 & 10.39 & 10.55 \\
\hline $\mathrm{Na}_{2} \mathrm{O}$ & 2.53 & 2.50 & 2.56 & 2.86 & 2.95 & 3.70 & 2.87 & 3.00 & 3.07 \\
\hline $\mathrm{K}_{2} \mathrm{O}$ & 1.06 & 0.35 & 0.41 & 0.93 & 0.88 & 0.96 & 0.83 & 0.84 & 0.80 \\
\hline $\mathrm{TiO}_{2}$ & 1.04 & 1.01 & 1.03 & 1.67 & 1.67 & 1.67 & 1.63 & 1.66 & 1.66 \\
\hline $\mathrm{P}_{2} \mathrm{O}_{5}$ & 0.16 & 0.10 & 0.10 & 0.30 & 0.30 & 0.30 & 0.28 & 0.29 & 0.31 \\
\hline $\mathrm{CO}_{2}$ & 1.85 & 0.88 & 0.00 & 0.00 & 0.00 & 0.17 & 0.00 & 0.00 & 0.00 \\
\hline PF & 2.90 & 3.50 & 2.13 & 3.59 & 2.63 & 3.18 & 2.59 & 2.74 & 2.55 \\
\hline Total & 100.10 & 100.45 & 100.22 & 100.63 & 97.95 & 99.27 & 99.94 & 100.60 & 98.91 \\
\hline \multicolumn{10}{|l|}{ Norms } \\
\hline Q & 3.40 & 2.27 & 2.82 & 0.86 & 0.00 & 0.00 & 0.00 & 0.38 & 0.00 \\
\hline ne & 0.00 & 0.00 & 0.00 & 0.00 & 0.00 & 1.63 & 0.00 & 0.00 & 0.00 \\
\hline or & 6.26 & 2.06 & 2.42 & 5.49 & 5.20 & 5.67 & 4.90 & 4.96 & 4.72 \\
\hline$a b$ & 21.40 & 21.15 & 21.66 & 24.20 & 24.96 & 28.29 & 24.28 & 25.38 & 25.97 \\
\hline an & 33.97 & 34.62 & 34.99 & 28.23 & 28.39 & 25.00 & 29.71 & 29.29 & 28.96 \\
\hline (wo & 8.08 & 10.58 & 10.59 & 10.75 & 8.53 & 10.68 & 8.61 & 8.49 & 8.91 \\
\hline \multirow{2}{*}{ di $\left\{\begin{array}{l}\text { en } \\
\text { fs }\end{array}\right.$} & 6.98 & 9.14 & 8.10 & 7.98 & 5.80 & 8.97 & 5.97 & 5.83 & 5.91 \\
\hline & 0.00 & 0.00 & 1.38 & 1.73 & 2.06 & 0.33 & 1.93 & 1.97 & 2.35 \\
\hline \multirow{2}{*}{ hy $\left\{\begin{array}{l}\text { en } \\
\text { fs }\end{array}\right.$} & 0.60 & 4.30 & 4.69 & 6.78 & 7.20 & 0.00 & 10.58 & 10.27 & 6.67 \\
\hline & 0.00 & 0.00 & 0.80 & 1.47 & 2.56 & 0.00 & 3.43 & 3.48 & 2.65 \\
\hline fo & 0.00 & 0.00 & 0.00 & 0.00 & 2.19 & 4.05 & 0.29 & 0.00 & 1.91 \\
\hline fa & 0.00 & 0.00 & 0.00 & 0.00 & 0.85 & 0.16 & 0.10 & 0.00 & 0.83 \\
\hline $\mathrm{mt}$ & 7.29 & 6.74 & 8.42 & 5.65 & 3.68 & 7.01 & 3.75 & 3.94 & 3.56 \\
\hline ilm & 1.97 & 1.91 & 1.95 & 3.17 & 3.17 & 3.17 & 3.09 & 3.15 & 3.15 \\
\hline ap & 0.37 & 0.23 & 0.23 & 0.70 & 0.70 & 0.70 & 0.66 & 0.68 & 0.73 \\
\hline $\mathrm{rt}$ & 0.00 & 0.00 & 0.00 & 0.00 & 0.00 & 0.00 & 0.00 & 0.00 & 0.00 \\
\hline $\mathrm{hm}$ & 2.62 & 2.92 & 0.00 & 0.00 & 0.00 & 0.00 & 0.00 & 0.00 & 0.00 \\
\hline c & 0.00 & 0.00 & 0.00 & 0.00 & 0.00 & 0.00 & 0.00 & 0.00 & 0.00 \\
\hline $\mathrm{cc}$ & 4.20 & 2.00 & 0.00 & 0.00 & 0.00 & 0.38 & 0.00 & 0.00 & 0.00 \\
\hline C.I. & 49.10 & 54.77 & 32.54 & 46.13 & 43.83 & 48.42 & 43.96 & 42.92 & 44.30 \\
\hline D.I. & 31.07 & 25.49 & 26.91 & 30.56 & 30.16 & 35.60 & 29.18 & 30.73 & 30.70 \\
\hline
\end{tabular}

Note: $\mathrm{PF}=$ ignition C.I. $=$ crystallization index D.I. $=$ differentiation index.

to the one encountered above the tuff. The upper and lower part of this flow contain zones with large vesicles (Figure 2). This basaltic layer overlies a dark greenish gray (5 GY 5/1) amygdalar basalt (Core 54, Section 1; see Figure 3 ) which is followed by a very coarse-grained dark greenish gray (5 GY 5/1) homogeneous basaltic flow (Core 54, Section 2; see Figure 3). The last core of the drill site terminates at 495 meters under the sea floor and consists of alternating zones (20-50 cm thick) of vesicular, amygdalar, and phaneritic homogenous basalts.

Two main types of rocks were found at this site (214). The first is an intermediate differentiated type of rock forming the upper part of the drilled rock unit and comprising Core 48, Sections 1, 2, Core 49, Sections 1, 2, Cores 50 and 51 . The second is a basaltic rock located in Core 53, Sections 1 and 2 and in Core 54, Sections 1, 2, and 3 (Figure 3 ).

\section{Intermediate Differentiated Rock}

The name "intermediate differentiated rock" has been given because of the lack of another name appropriate to the chemistry and mineralogy of the rocks. The differentiated flow occurs in Cores 48, 49, 50, and 51. The texture is pilotaxitic and trachytic, and the plagioclase is more sodic than $\mathrm{An}_{35}$. The rocks are usually hypocrystalline non-porphyritic containing laths $(<0.5 \mathrm{~mm}$ 
length) of oligoclase-andesine set in a light brown glassy matrix. Small aggregates of felsics containing K-feldspar were detected in the groundmass. The size of the plagioclase varies between 0.02 to $0.4 \mathrm{~mm}$ in length. The twinnings of the plagioclase are according to the pericline, albite, and albite-carlsbad laws. Interpenetration twins of zoned plagioclase crystals are present (Plate 2, Figure 7). The clinopyroxene $\left(2 \mathrm{~V}=46^{\circ}-51^{\circ}\right)$ is a colorless anhedral augite with a diameter of less than $0.8 \mathrm{~mm}$. Iron oxide minerals, euhedral and anhedral, occur throughout. Usually the size of the iron oxide minerals is between 0.08 and 0.15 $\mathrm{mm}$ in diameter. However, sometimes the iron oxide minerals reach the size of euhedral microphenocrysts $(\simeq 0.4$ $\mathrm{mm}$ diameter) $(48-2,117-123 \mathrm{~cm})$. These microphenocrysts are surrounded by microlites of plagioclase (50-1, 145-150 $\mathrm{cm})$. Calcite occurs either as interstitial material between plagioclase laths or occasionally forms the core of some clinopyroxene granules. Traces of apatite needles are included in the plagioclase laths. The vesicles, comprising about 3 to $5 \%$ of the bulk rock, are oval and sometimes elongated according to the direction of flow. Rare microphenocrysts ( $>0.5 \mathrm{~mm}$ length) of plagioclase and plagioclase phenocrysts (1.3 mm length) occur $(48-1,125-133 \mathrm{~cm}$ and 48-1, 137-144 cm). In the lower part of the flow (Core 50 , Section 1, down), only the larger plagioclase laths show preferential orientation, while the matrix is randomly oriented.

The chemical analyses and the norms of the upper rock unit of Site 214 are shown in Table 7. These rocks are characterized by a high $\mathrm{SiO}_{2}$ content $(54-59 \%)$, a high total iron content $(>11 \%)$, high $\mathrm{Na}_{2} \mathrm{O}$ and $\mathrm{K}_{2} \mathrm{O}$ contents, a low $\mathrm{MgO}(<3 \%)$ content, and a low $\mathrm{CaO}$ content $(<6 \%)$. The $\mathrm{TiO}_{2}$ content is less than $2 \%$ and the $\mathrm{Al}_{2} \mathrm{O}_{3}$ content is variable between 15 and $19 \%$. The normative quartz content varies between 8 and $12 \%$. The normative orthoclase content is less than $10 \%$. The normative albite content is higher than the normative anorthite content. Hence, from the chemical data, the textural aspect, and the plagioclase composition, it is most appropriate to call these rocks oceanic andesites.

\section{Basalt}

The basalts from Site 214 are divided according to their appearance into two types: the non-vesiculated homogeneous basalt and the vesicular and amygdalar basalt.

\section{Non-Vesicular Basalt}

This type of basalt is located above the vesicular and amygdalar basalt. This flow (Core 53, Sections 1 and 2) has an upper chilled contact about 20 centimeters thick. The basalt is dark gray (M 3) and varies from an aphanitic texture in the upper part (Core 53, Section 1) to a phaneritic and more crystalline rock in the inner portion of the unit and finally to an aphanitic rock in the lower part (Core 53, Section 2), which is in contact with a thin tuffaceous layer. This unit of Core 53, Section 2 was broken up into pebble-size fragments during the drilling operation. Another basaltic flow, which is slightly amygdalar and gradually passes down into a coarse-grained dark greenish gray (5 GY 5/1) holocrystalline basalt, occurs in Core 54, Sections 1 and 3 (Plate 2, Figure 10). Both of the flows located in Cores 53 and 54 are chemically and mineralogically similar (Figure 2). These rocks are intergranular with abundant plagioclase laths and have an average length of about $0.5 \mathrm{~mm}$. Rare plagioclase phenocrysts $(1-1.6 \mathrm{~mm}$ in length) $(53-1,10-11 \mathrm{~cm})$ occur either as individual laths or in agglomerates. The plagioclase occurs either as very fresh $(53-3,26-30 \mathrm{~cm})$ or as altered laths (53-1, at intervals $10-11 \mathrm{~cm}, 30-35 \mathrm{~cm}, 59-62 \mathrm{~cm}$, and $97-100 \mathrm{~cm}$ ) (Plate 2, Figure 9). The alteration product consists of green chlorite and greenish yellow mixed layer vermiculite-smectite. Chlorite and vermiculite also occur as alteration products of the matrix. Shaped like a rosette with radiating fibers, vermiculite-smectite occurs in veins, in small vesicles, and in irregular patches (Plate 2, Figure 8). The patches have either a "shard-like" or an oval outline containing concentric rims of palagonite and vermiculite. The clinopyroxene is an abundant constituent of these rocks $(<50 \%)$. It appears as pale green and colorless $(2$ $\left.\mathrm{V}=56^{\circ}-55^{\circ}\right)$ anhedral granules $(0.07-0.3 \mathrm{~mm}$ in diameter). Sometimes these clinopyroxenes form cumulates. The opaques consist of titanomagnetite having euhedral and skeletal forms. Traces of biotite occur in association with the chlorite of the matrix or between cleavage planes of the clinopyroxene. Small amounts of calcite occur in veins and as interstitial material between plagioclase laths.

\section{Amygdalar and Vesicular Basalts}

This type occurs in Core 54, Section 3 and consists of abundant vesicles $(>10 \%)$ having rounded, oval, elongated, and irregular shapes. The size of these vesicles varies between $1 \mathrm{~mm}$ and $10 \mathrm{~mm}$ in diameter, and the larger vesicles are more abundant. The amygdules consist of vesicles filled by calcite, rimmed by palagonite, and occur as zones about $20 \mathrm{~cm}$ thick which alternate with the vesicular zones. The vesicular zones are thicker $(\simeq 30 \mathrm{~cm}$ thick) (Figure 2) than the amygdalar zone. The amygdalar and vesicular basalts occur in Core 54, Section 3 (Figure 2) associated with one $35 \mathrm{~cm}$ thick dark greenish gray (5 GY 5/1) coarse-grained basalt similar to that found in Cores 53 and 54 (Section 2). The amygdalar and vesicular basalts show a generally fresh aspect with the exception of some palagonatized zones forming shard-like patches in the groundmass of these rocks. They are porphyritic with a subophitic and interstitial texture. The matrix plagioclase varies between 0.2 and $0.8 \mathrm{~mm}$ in length and comprises about 40 to $45 \%$ of the bulk rock (Table 3 ). The plagioclase phenocrysts are less abundant $(<2 \%)$ and vary between 1.1 and $2.5 \mathrm{~mm}$ in length. The composition of the matrix plagioclase and phenocrysts is $\mathrm{An}_{45}-\mathrm{An}_{57}$. The clinopyroxene $\left(2 \mathrm{~V}=45^{\circ}-55^{\circ}\right)$ occurs in plates of 0.08 to 0.6 $\mathrm{mm}$ in diameter and comprises about 40 to $50 \%$ of the bulk rock (Table 2). The clinopyroxene is colorless and fresh and may also form cumulates. Euhedral and anhedral iron oxide minerals $(<10 \%)$, reaching up to 0.2 millimeters in diameter, occur as do traces of brown tiny flakes and needles of biotite associated with serpentine and with iron oxide minerals. The amount of phyllosilicates in the amygdalar and vesicular basalts is variable (3-15\%) (Table 3). 
TABLE 7

Chemical Analyses and Norms of Differentiated Igneous Rock Samples, Site 214

\begin{tabular}{|c|c|c|c|c|c|c|c|c|}
\hline & \multicolumn{7}{|c|}{$\begin{array}{l}\text { Chemical Analyses and Norms of Differentiated } \\
\text { Igneous Rock Samples, Site } 214\end{array}$} & \multirow[b]{2}{*}{$41^{\mathrm{a}}$} \\
\hline & 33 & 34 & 35 & 37 & 38 & 39 & 40 & \\
\hline $\mathrm{iO}_{2}$ & 56.69 & 54.79 & 55.70 & 54.59 & 57.41 & 58.02 & 55.70 & 51.34 \\
\hline $\mathrm{A}_{2}{ }_{2} \mathrm{O}_{3}$ & 16.10 & 15.82 & 15.40 & 15.67 & 15.81 & 15.95 & 15.30 & 18.73 \\
\hline $\mathrm{Fe}_{2} \mathrm{O}_{3}$ & 2.88 & 3.61 & 3.11 & 2.42 & 2.83 & 2.17 & 2.91 & 3.80 \\
\hline $\mathrm{FeO}$ & 7.55 & 6.45 & 7.00 & 7.47 & 7.00 & 7.51 & 7.00 & 2.72 \\
\hline $\mathrm{MgO}$ & 2.57 & 2.60 & 2.40 & 2.60 & 2.32 & 2.33 & 2.30 & 1.02 \\
\hline $\mathrm{CaO}$ & 5.62 & 5.67 & 5.59 & 5.82 & 5.86 & 5.71 & 5.71 & 7.97 \\
\hline $\mathrm{Na}_{2} \mathrm{O}$ & 4.08 & 4.12 & 3.88 & 3.88 & 3.92 & 3.70 & 3.78 & 4.21 \\
\hline $\mathrm{K}_{2} \mathrm{O}$ & 1.56 & 1.36 & 1.55 & 1.27 & 1.58 & 1.56 & 1.49 & 1.83 \\
\hline $\mathrm{TiO}_{2}$ & 1.40 & 1.39 & 1.40 & 1.43 & 1.46 & 1.47 & 1.44 & 1.56 \\
\hline $\mathrm{P}_{2} \mathrm{O}_{5}$ & 0.56 & 0.59 & 0.63 & 0.68 & 0.65 & 0.64 & 0.66 & 0.80 \\
\hline $\mathrm{CO}_{2}$ & 0.00 & 0.00 & 0.00 & 0.00 & 0.00 & 0.00 & 0.00 & 1.76 \\
\hline $\mathrm{PF}^{\mathrm{b}}$ & 1.22 & 1.89 & 1.15 & 1.99 & 1.18 & 0.91 & 1.42 & 5.06 \\
\hline Total & 100.22 & 98.28 & 97.80 & 97.79 & 100.01 & 99.96 & 97.70 & 100.79 \\
\hline & & & & & & & & \\
\hline & 10.21 & 9.05 & 10.56 & 9.10 & 11.54 & 12.66 & 11.31 & 8.31 \\
\hline r & 9.21 & 8.03 & 9.15 & 7.50 & 9.33 & 9.21 & 8.80 & 10.81 \\
\hline$a b$ & 34.52 & 34.86 & 32.83 & 32.83 & 33.16 & 31.30 & 31.98 & 35.62 \\
\hline in & 21.00 & 20.65 & 20.02 & 21.59 & 20.87 & 22.30 & 20.37 & 23.18 \\
\hline (wo & 1.34 & 1.51 & 1.49 & 1.18 & 1.64 & 0.76 & 1.51 & 0.00 \\
\hline di $\{$ en & 0.55 & 0.73 & 0.64 & 0.48 & 0.68 & 0.29 & 0.63 & 0.00 \\
\hline fs & 0.79 & 0.74 & 0.85 & 0.70 & 0.96 & 0.48 & 0.89 & 0.00 \\
\hline & 5.84 & 5.73 & 5.33 & 5.98 & 5.08 & 5.50 & 5.09 & 2.54 \\
\hline & 8.37 & 5.81 & 7. & 8.6 & 7 & 9.08 & 7.18 & 0.00 \\
\hline $\mathrm{mt}$ & 4.17 & 5.23 & 4.50 & 3.50 & 4.10 & 3.14 & 1 & 4 \\
\hline ilm & 265 & 2.63 & 2.65 & 2.71 & 2.77 & 2.79 & 2. & 2.96 \\
\hline ap & 1.32 & 1.39 & 1.48 & 1.60 & 1.53 & 1.50 & 1.55 & 1.88 \\
\hline $\mathrm{hm}$ & 0.00 & 0.00 & 0.00 & 0.00 & 0.00 & 0.00 & 0.00 & 0.87 \\
\hline 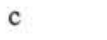 & 0.00 & 0.00 & 0.00 & 0.00 & 0.00 & 0.00 & 0.00 & 1.32 \\
\hline 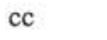 & 0.00 & 0.00 & 0.00 & 0.00 & 0.00 & 0.00 & 0.00 & 4.00 \\
\hline Total & 100.03 & 96.42 & 96.68 & 95.83 & 98.86 & 99.08 & 96.31 & 95.77 \\
\hline C.I. ${ }^{c}$ & 22.79 & 22.82 & 21.95 & 23.24 & 22.87 & 23.49 & 22.25 & 23.43 \\
\hline D.I. ${ }^{d}$ & 5395 & 51.94 & 52.55 & 49.43 & 54.04 & 53.19 & 52.10 & 54.75 \\
\hline
\end{tabular}

${ }^{\text {a Sample }} 41$ is near the lower contact of the flow.

${ }^{\mathrm{b}} \mathrm{PF}$ indicates ignition.

${ }^{c} \mathrm{C}$ I. indicates the crystallization index.

${ }^{d}$ D.I. is the differentiation index.

\section{Chemical Composition of Basalts}

The two types of basaltic rocks show a fairly constant chemical composition throughout the drilled cores (Table 8). The $\mathrm{SiO}_{2}$ content $(<48 \%)$ and the $\mathrm{Al}_{2} \mathrm{O}_{3}$ content $(<15 \%)$ are relatively low. The $\mathrm{K}_{2} \mathrm{O}$ content is also relatively low $(<3 \%)$. These rocks have a high total iron content $(>11 \%)$. The high $\mathrm{H}_{2} \mathrm{O}$ content $(<4 \%)$ is mainly due to the presence of phyllosilicates, probably of late deuteric origin. These basalts have less than $5 \%$ normative quartz and normative hypersthene of 10 to $19 \%$ (Table 8 ).

\section{Site 215}

This site is located in the Central Indian Ocean Basin (Figure 1). The rocks recovered from the site consist of weathered and moderately fresh basalts buried under 150.8 meters of sediment. The sediment in direct contact with the basalt is a nanno ooze. Drilling was terminated at a total depth of 175 meters (Figure 2).

The rocks from Site 215 are similar to, but less weathered than those from Site 213. They form a succession of pillow-lavas of which at least fourteen were 
TABLE 8

Chemical Analyses and Norms of Basalt Samples, Site 214

\begin{tabular}{|c|c|c|c|c|c|c|}
\hline & 42 & 43 & 44 & 45 & 46 & 47 \\
\hline $\mathrm{SiO}_{2}$ & 45.50 & 42.70 & 43.96 & 47.71 & 45.32 & 43.94 \\
\hline $\mathrm{Al}_{2} \mathrm{O}_{3}$ & 14.70 & 13.53 & 13.51 & 13.47 & 14.70 & 13.65 \\
\hline $\mathrm{Fe}_{2} \mathrm{O}_{3}$ & 6.82 & 7.73 & 5.99 & 5.21 & 5.31 & 7.09 \\
\hline $\mathrm{FeO}^{\mathrm{a}}$ & 7.69 & 8.00 & 8.96 & 8.00 & 8.00 & 8.61 \\
\hline $\mathrm{MgO}$ & 6.22 & 6.49 & 6.59 & 5.87 & 5.59 & 6.07 \\
\hline $\mathrm{CaO}$ & 8.88 & 7.42 & 8.37 & 9.98 & 8.50 & 6.84 \\
\hline $\mathrm{Na}_{2} \mathrm{O}$ & 2.40 & 1.85 & 2.28 & 2.60 & 2.73 & 2.95 \\
\hline $\mathrm{K}_{2} \mathrm{O}$ & 0.21 & 0.29 & 0.30 & 0.18 & 0.81 & 0.26 \\
\hline $\mathrm{TiO}_{2}$ & 2.12 & 2.02 & 2.03 & 2.25 & 2.14 & 2.50 \\
\hline $\mathrm{P}_{2} \mathrm{O}_{5}$ & 0.17 & 0.14 & 0.16 & 0.18 & 0.18 & 0.21 \\
\hline $\mathrm{CO}_{2}$ & 0.00 & 0.00 & 0.00 & 0.17 & 0.00 & 0.00 \\
\hline $\mathrm{PF}^{\mathrm{b}}$ & 5.80 & 8.56 & 7.16 & 4.31 & 5.28 & 6.62 \\
\hline Total & 100.50 & 98.72 & 99.30 & 99.92 & 97.92 & 98.73 \\
\hline \multicolumn{7}{|l|}{ Norms } \\
\hline Q & 371 & 5.14 & 1.71 & 4.60 & 2.58 & 2.03 \\
\hline or & 1.24 & 1.71 & 1.77 & 1.06 & 1.06 & 1.53 \\
\hline$a b$ & 20.30 & 15.65 & 19.29 & 22.00 & 23.10 & 24.96 \\
\hline an & 28.71 & 27.65 & 25.74 & 24.55 & 27.32 & 23.23 \\
\hline (wo & 5.93 & 3.39 & 6.15 & 9.48 & 5.70 & 3.89 \\
\hline \multirow{2}{*}{ di $\{$ en } & 4.12 & 2.37 & 3.85 & 6.08 & 3.59 & 2.60 \\
\hline & 1.32 & 0.73 & 1.91 & 2.77 & 1.75 & 1.00 \\
\hline \multirow{2}{*}{ hy $\left\{\begin{array}{l}\text { en } \\
\text { fs }\end{array}\right.$} & 11.36 & 13.78 & 12.55 & 8.53 & 10.32 & 12.51 \\
\hline & 3.65 & 4.23 & 6.23 & 3.89 & 5.01 & 4.82 \\
\hline $\mathrm{mt}$ & 9.88 & 11.20 & 8.68 & 7.55 & 7.69 & 10.27 \\
\hline ilm & 4.02 & 3.83 & 3.85 & 4.27 & 4.06 & 4.74 \\
\hline ap & 0.40 & 0.33 & 0.37 & 0.42 & 0.42 & 0.49 \\
\hline $\mathrm{hm}$ & 0.00 & 0.00 & 0.00 & 0.00 & 0.00 & 0.00 \\
\hline $\mathrm{cc}$ & 0.00 & 0.00 & 0.00 & 0.00 & 0.00 & 0.00 \\
\hline $\mathrm{cc}$ & 0.00 & 0.00 & 0.00 & 0.38 & 0.00 & 0.00 \\
\hline Total & 94.71 & 90.17 & 92.15 & 95.62 & 92.65 & 92.12 \\
\hline $\mathrm{CI}^{\mathrm{c}}$ & 38.75 & 34.28 & 35.33 & 38.53 & 36.13 & 30.11 \\
\hline D.I. ${ }^{d}$ & 25.26 & 22.51 & 22.77 & 27.66 & 26.74 & 28.53 \\
\hline
\end{tabular}

${ }^{a}$ Value of 8 percent was given to $\mathrm{FeO}$ for calculation of

Samples 4345 and 46 .

$\mathrm{b}_{\mathrm{PF}}=$ ignition

${ }^{c} \mathrm{C} I .=$ crystallization index

$\mathrm{d}_{\mathrm{D} . \mathrm{I}}=$ differentiation index

counted, varying from $50 \mathrm{~cm}$ to 5 meters in thickness. Each of these pillow-lavas shows three texturally different zones:

1) There is an upper and a lower glassy surface $(<2 \mathrm{~cm}$ thick) which contain veins of palagonite and calcite. Sometimes between the chilled margins of two pillow-lavas there are some indurated carbonates (limestone) (Plate 1, Figure 2). These glassy margins also contain olivine and plagioclase phenocrysts.

2) The transitional zone is hypocrystalline, aphanitic, and moderately weathered. It is made up of a dark mesostasis, felted plagioclase laths, and its general texture is variolitic and intersertal. The size of the plagioclase laths does not exceed $0.4 \mathrm{~mm}$ in length. Completely altered and unrecognizable ferromagnesians occur.

3) The inner, more crystalline and less weathered zone of these pillow-lavas consists of holocrystalline rock with intergranular and subophitic texture. The plagioclase $\left(\mathrm{An}_{45}-\mathrm{An}_{62}\right)$ occurs in prismatic and elongated laths (0.5-1.1 mm in length). The clinopyroxene $\left(2 \mathrm{~V}=49^{\circ}-55^{\circ}\right)$ is fresh and occurs in anhedral plates and elongated rods interpenetrated with the plagioclase (Plate 2, Figure 5). Small $(0.07-0.2 \mathrm{~mm}$ in diameter) crystals of olivine $\left(2 \mathrm{~V}=82^{\circ}-84^{\circ}\right)$ surrounded by a rim of serpentine are occasionally seen in the groundmass. In the least crystalline specimens, the groundmass contains a dark mesostasis, microlites of plagioclase, and incipient arborescent clinopyroxene. A few small vesicles $(0.2-0.3 \mathrm{~mm}$ in diameter) are scattered throughout.

Six chemical analyses and their respective norms are shown in Table 6 . No substantial variations between the several pillow-lavas analyzed were noticed. The $\mathrm{SiO}_{2}$ varies between 47 and $50 \%$. The low value of $47 \%$ for the silica is attributed to weathering since the analyzed sample contained more $\mathrm{H}_{2} \mathrm{O}(3 \%)$ and more $\mathrm{Fe}_{2} \mathrm{O}_{3}(5 \%)$ than the other samples (Table 6). The $\mathrm{Al}_{2} \mathrm{O}_{3}$ and the $\mathrm{TiO}_{2}$ content of these rocks have constant values of 16 to $17 \%$ and $1.7 \%$, respectively. The $\mathrm{K}_{2} \mathrm{O}$ content varies around $0.8 \%$ except for the most weathered specimen where the value of potash is close to $1 \%$ (Table 6 ). The normative calculations show the lack of nepheline, the rare occurrence of quartz $(<1 \%)$ in two specimens, and a small amount of olivine $(<5 \%)$ in the other four samples (Table 6). The normative hypersthene content of the freshest specimens varies between 9 and $15 \%$ (Table 6).

\section{Site 216}

The igneous rocks from Site 216 on the Ninetyeast Ridge are buried under 457.2 meters of sediment. The lowest sediment unit in contact with the rocks (Core 36, Section 3) consists of a clay-rich and chlorite-rich limestone mixed with volcanic debris (Figure 2). This is followed by two thin flows ( $<1$ meter thick) of medium dark gray (N4) vesicular and amygdalar basalts separated from each other by a glassy margin and a chlorite-rich micritic limestone (Core 36, Sections 3 and 4) (Figure 2). The lower part of this vesicular and amygdalar flow is in contact with a pale green (10 G 6/2) volcanoclastic sediment (about $1 \mathrm{~m}$ thick). A pale red (5 R 6/2) oxidized scoriaceous basalt, which was not entirely cored, occurs in Core 37, Section 1 (Figure 2). This is intimately associated with an aphanitic basaltic rock (Core 37, Sections 1, 2, and 3; Figure 2) passing gradually to a thin $(<40 \mathrm{~cm}$ thick) vesicular zone with vesicles reaching up to $1 \mathrm{~cm}$ in diameter in Core 37 , Section 3 (Figure 2). The bottom contact of this vesicular basalt is sharply defined with the next unit which consists of a medium gray (N5) basalt in Core 37, Section 4 and in Core 38 , Section 2 (Figure 2). This medium gray basalt contains a few altered light olive gray ( 5 Y $5 / 2$ ) zones enriched in opaques (Figure 2). The lower contact of this basaltic flow consists of a zone where vesicularity increases gradually and terminates with a pale red oxidized scoriaceous basalt similar to Core 37, Section 1 (Figure 2). The bottom of the drilled hole (Core 38, Sections 3 and 4) consists of 


\section{R. HEKINIAN}

alternating flows of highly vesicular basalt, amygdalar basalts ( $<1$ meter thick), and homogeneous basalts (Figure 2). The drill hole terminated at 477.5 meters under the sea floor.

The rocks from Site 216 have been divided into two groups according to their textural features: vesicular and amygdalar basalts, and homogeneous non-vesiculated basalts.

\section{Vesicular and Amygdalar Basalts}

The vesicular and the amygdalar basalts are grouped together since no substantial variations were found between them. The amygdules may contain either calcite or a chlorite-smectite association. The vesicles and amygdules average about half a centimeter in diameter. The rocks are porphyritic with an intersertal texture. Phenocrysts of plagioclase are sometimes altered at their center by a yellowish brown material which is probably clay. The plagioclase of the matrix is a labradorite and comprises about $60 \%$ of the bulk rock (Table 3). Colorless clinopyroxene $\left(2 \mathrm{~V}=55^{\circ}-56^{\circ}\right)$ occurs in plates between plagioclase laths and in granules in the matrix. Usually the amount of clinopyroxene of the rocks is less $(<25 \%)$ than the amount of plagioclase. Phyllosilicates $(<10 \%)$ consisting of chlorite, vermiculite, smectite, and small amounts of serpentine occur in the matrix as the alteration products of glass and ferromagnesians. The iron oxide minerals (about $10 \%$ ) occur as anhedral crystals and elongated needles throughout the rocks. Hematite appears to be the alteration product of the iron oxides. Within the vesicular and amygdalar basalt located near the bottom of the drilled hole (Core 38, Section 4, $80-86 \mathrm{~cm}$ and in the core catcher), some rounded and shard-like green patches occur. These patches $(<1 \mathrm{~cm}$ in diameter) contain light brown smectite rimmed with green biotite needles and chlorite. They are similar to those found in the non-vesiculated basaltic zone described next.

Two chemical analyses of the rocks are shown in Table 9. One of the analyses of an amygdalar basalt located near the top of the drilled rock unit (Core 36, Section 4, 33-40 $\mathrm{cm}$ ) shows a lower content in total iron $(<11 \%)$ and a higher $\mathrm{K}_{2} \mathrm{O}$ content $(>1 \%)$ than the vesicular basalt containing green patches and located at the bottom of the drilled hole (Core 38, Section 4, in the core catcher). The sample from Core 36 is weathered and shows a lower $\mathrm{SiO}_{2}$ $(<46 \%)$ and higher $\mathrm{H}_{2} \mathrm{O}(>5 \%)$ than the sample from Core 38 (Table 9).

\section{Non-vesicular Basalt}

The homogeneous basalt has been subdivided according to its physical appearance into two zones: the patchy basalt zone and the pyroxene enriched basalt zone.

\section{The Patchy Basalt}

This zone occurs near the top of the extrusives (Core 37, Sections 1, 2, and 3). The upper contact of this zone is aphanitic and contains an abundant dark mesostasis, indicating a chilled margin in contact with the scoriaceous zone. The lower part has a gradational contact with a highly vesiculated zone (Figure 2). Patches up to $1 \mathrm{~cm}$ in diameter are sporadically scattered throughout the unit. The form of
TABLE 9

Chemical Analyses and Norms of Basalts, Site 216

\begin{tabular}{|c|c|c|c|c|c|c|c|}
\hline & \multicolumn{4}{|c|}{ Patchy Basalt Samples } & \multicolumn{2}{|c|}{$\begin{array}{c}\text { Pyroxene } \\
\text { Basalt Samples }\end{array}$} & \multirow{2}{*}{\begin{tabular}{|c|c|}
$\begin{array}{c}\text { Ves. } \\
\text { Basalt } \\
\text { Samples }\end{array}$ \\
30 \\
\end{tabular}} \\
\hline & 23 & 24 & 25 & 26 & 28 & 29 & \\
\hline $\mathrm{iO}_{2}$ & 45.76 & 48.56 & 48.14 & 48.07 & 49.04 & 50.43 & 48.67 \\
\hline $\mathrm{A}_{2}{ }_{2} \mathrm{O}_{3}$ & 13.07 & 13.67 & 13.00 & 13.22 & 12.97 & 12.96 & 12.63 \\
\hline $\mathrm{Fe}_{2} \mathrm{O}_{3}$ & 6.49 & 5.65 & 6.46 & 5.41 & 5.79 & 6.12 & 6.04 \\
\hline $\mathrm{FeO}^{\mathrm{a}}$ & 8.00 & 7.45 & 8.00 & 8.00 & 9.16 & 8.00 & 7.15 \\
\hline $\mathrm{MgO}$ & 6.22 & 6.52 & 5.67 & 6.85 & 5.33 & 5.98 & 6.55 \\
\hline $\mathrm{CaO}$ & 8.16 & 8.39 & 9.18 & 7.42 & 9.31 & 9.45 & 9.10 \\
\hline $\mathrm{Na}_{2} \mathrm{O}$ & 2.53 & 2.50 & 2.41 & 2.63 & 2.50 & 2.59 & 2.30 \\
\hline $\mathrm{K}_{2} \mathrm{O}$ & 1.29 & 0.44 & 0.73 & 0.57 & 0.83 & 0.54 & 0.90 \\
\hline $\mathrm{TiO}_{2}$ & 2.71 & 2.76 & 2.65 & 2.76 & 2.64 & 2.72 & 2.50 \\
\hline $\mathrm{P}_{2} \mathrm{O}_{5}$ & 0.22 & 0.22 & 0.21 & 0.21 & 0.22 & 0.22 & 0.19 \\
\hline $\mathrm{CO}_{2}$ & 0.00 & 0.00 & 0.00 & 0.00 & 0.00 & 0.00 & 0.00 \\
\hline $\mathrm{PF}^{\mathrm{b}}$ & 4.26 & 4.06 & 2.29 & 4.90 & 0.99 & 1.22 & 3.71 \\
\hline Cotal & 98.71 & 100.21 & 98.73 & 100.03 & 98.77 & 100.22 & 99.73 \\
\hline \multicolumn{8}{|l|}{ Norms } \\
\hline 0 & 2.51 & 6.55 & 6.21 & 5.27 & 5.52 & 7.44 & 6.13 \\
\hline r & 7.62 & 260 & 4.31 & 3.36 & 4.90 & 3.19 & 5.31 \\
\hline b & 21.40 & 21.15 & 20.39 & 22.25 & 21.15 & 21.91 & 19.46 \\
\hline n & 20.49 & 24.77 & 22.49 & 2258 & 21.71 & 22.14 & 21.48 \\
\hline (wo & 7.74 & & 9.04 & 5.36 & 9.61 & .72 & 9.36 \\
\hline di $\{$ en & 5.78 & 4.59 & 6.16 & 3.70 & 5.77 & .65 & 6.81 \\
\hline$l_{\text {fs }}$ & 1.19 & 1.26 & 2.17 & 1.22 & 3.33 & 2.29 & 1.67 \\
\hline$y<\int^{e n}$ & 9.70 & 11.63 & 7.95 & 13.35 & 7.50 & 8.23 & 9.49 \\
\hline${ }^{1}$ Is $_{\text {s }}$ & 2.00 & 3.19 & 2.80 & 4.43 & 4.33 & 2.84 & 2.33 \\
\hline $\mathrm{mt}$ & 12.30 & 8.19 & 9.36 & 7.84 & 8.39 & 8.87 & 8.75 \\
\hline ilm & 5.14 & 5.24 & 5.03 & 5.24 & 5.01 & 5.16 & 4.74 \\
\hline ap & 0.51 & 0.51 & 0.49 & 0.49 & 0.51 & 0.51 & 0.44 \\
\hline $\mathrm{hm}$ & 0.00 & 0.00 & 0.00 & 0.00 & 0.00 & 0.00 & 0.00 \\
\hline 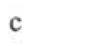 & 0.00 & 0.00 & 0.00 & 0.00 & 0.00 & 0.00 & 0.00 \\
\hline $\mathrm{cc}$ & 0.00 & 0.00 & 0.00 & 0.00 & 0.00 & 0.00 & 0.00 \\
\hline Total & 96.45 & 96.16 & 96.45 & 95.14 & 97.79 & 99.01 & 96.03 \\
\hline C.I. ${ }^{c}$ & 33.95 & 35.87 & 36.60 & 31.91 & 34.92 & 37.33 & 37.14 \\
\hline D.I. $^{d}$ & 31.54 & 30.31 & 30.91 & 30.89 & 31.58 & 32.55 & 30.91 \\
\hline
\end{tabular}

${ }^{a}$ Value of 8 percent was given to $\mathrm{FeO}$ for calculating the norm of samples 23, 25, 26, 29.

$\mathrm{b}_{\mathrm{PF}}=$ ignition

${ }^{c}$ C.I. = crystallization index.

$\mathrm{d}_{\text {D.I. }}=$ differentiation index.

the patches could be shard like with sharp edges, irregular, oval, or elongated. The patches are filled with vermiculitesmectite (brown patches), green biotite and chlorite (green patches), or with calcite rimmed by palagonite (white patches). X-ray studies of some of the green patches show the presence of mixed-layer chlorite-montmorillonite, as well as sphene granules and prismatic rutile. Rutile occurs in geniculated twins with a reddish brown color. The patchy basalts are aphanitic hypocrystalline and holocrystalline with a pilotaxitic and trachytic texture. The 
plagioclase of the matrix is oriented toward the direction of flow and has a tendency to bend around larger plagioclase microphenocrysts and amygdules. The plagioclase microphenocrysts (0.4-0.8 mm length) are rare and occur as individual grains or as agglomerate laths. Traces of plagioclase phenocrysts $(1.6 \mathrm{~m}$ length) were observed in Core 37 , Section $2,80-87 \mathrm{~cm}$. The clinopyroxene $(2 \mathrm{~V}=$ $56-58^{\circ}$ ) is colorless to pale green and occurs in small granules $(0.02-0.08 \mathrm{~mm}$ in diameter). The content of clinopyroxene is equal to, or less than, the plagioclase content (Table 3). Magnetite occurs as anhedral or euhedral grains. Some large crystals (average $0.15 \mathrm{~mm}$ in diameter) are resorbed, and some have a rim of hematite. The inclusion of plagioclase microlites and pyroxene granules was seen to occur in some of the larger magnetite grains. The matrix also contains smectite, chlorite, and yellowish brown glass.

\section{The Pyroxene Basalts}

This zone underlies the patchy basalt and occur in Core 37, Section 4 and in Core 38, Sections 1 and 2 (Figure 2). These are called pyroxene basalts because the amount of clinopyroxene exceeds the amount of plagioclase (Table 3 ). The lower contact of the pyroxene basalt is due to a gradual increase in vesicularity until the scoriaceous basalt zone is reached (Figure 2). The pyroxene basalt is aphanitic and holocrystalline with a pilotaxitic and intergranular texture. The clinopyroxene $\left(2 \mathrm{~V}-55-56^{\circ}\right)$ occurs in anhedral grains varying in size between 0.03 to $0.15 \mathrm{~mm}$. They always form agglomerates (cumulates) and their amount is higher than $40 \%$ (Plate 2, Figure 6). Some clinopyroxene is occasionally included in coarser plagioclase laths (microphenocrysts). Most clinopyroxene is fresh, and only a small amount is altered into chlorite. The iron oxide minerals $(<15 \%)$ are euhedral, and they may occur as individual grains or forming cumulates of several crystals together. Magnetite crystals often reach up to $0.3 \mathrm{~mm}$ in diameter and contain inclusions of plagioclase microlites and clinopyroxene granules. Phenocrysts $(1.3-1.5 \mathrm{~mm})$ and microphenocrysts of plagioclase are rare. The main form of plagioclase consists of laths averaging about $0.15 \mathrm{~mm}$ in length. The laths of plagioclase are usually fresh and occasionally contain small patches of chlorite. The phyllosilicates consist of chlorite and vermiculite-smectite $(<12 \%)$. Chlorite usually fills irregular shard-like patches in the matrix similar to the above patchy basalt zone. Skeletal iron oxide minerals are sometimes associated with chlorite. Vermiculite-smectite occurs as golden yellow and brown radiating fibers in the matrix and concentrated in certain zones (Core 38, Section 2, 79-85 $\mathrm{cm}$ and Core 38 , Section $2,143-150 \mathrm{~cm})$. Sometimes smectite has also filled tiny vesicles.

Within the pyroxene basalt zone, there are a few light olive gray $(5$ Y $1 / 2)$ altered basaltic zones which contain a colorless pale-brown diopside-hedenbergite and a matrix of some reddish brown amorphous aggregates, which may be limonite and sphene. The altered zone also contains veins of native copper.

\section{Chemical Composition of Non-vesicular Basalts}

The chemistry and the norms of the patchy basalts and the pyroxene-rich basalts of Site 216 do not show any substantial differences (Table 9). They both are characterized by a low $\mathrm{Al}_{2} \mathrm{O}_{3}$ content $(<15 \%)$, a high total iron oxide content $(>13 \%)$, and a high $\mathrm{TiO}_{2}$ content $(2-3 \%)$. The only differences between these two types of rocks is the higher $\mathrm{H}_{2} \mathrm{O}$ content for the patchy basalts, which are also enriched in phyllosilicate minerals with respect to the pyroxene basalt. Both types of basalts have quartz (2-7\%) and hypersthene (10-12\%) in their norms (Table 9). The anorthite content (about $22 \%$ ) of the normative plagioclase is close to the albite content (Table 9). The normative orthoclase content is variable (2-8\%) (Table 9).

\section{COMPARISON WITH OTHER INDIAN OCEAN VOLCANIC PROVINCES}

In order to compare the rocks from the northeastern Indian Ocean with other oceanic provinces, published analyses of rocks from the Indian Ocean north of $40^{\circ} \mathrm{S}$ have been considered. These provinces comprise the Indonesian Islands, as well as Christmas (Smith and Mountain, 1925), Rodrigues (Upton et al., 1967), Mauritius (Shand, 1932), Reunion (Upton and Wadsworth, 1966), Crozet (Gunn et al., 1970), New Amsterdam and St. Paul islands (Reinich, 1908). Also, published data on basaltic rocks and spilites from the M.I.O.R. have been used in this comparison.

Published data from the Indian Ocean are plotted on the total alkali-silica diagram of MacDonald and Katsura (1964) in Figures 5, 6, and 7. Figure 5 shows the total alkali-silica diagram of the basin floor rocks of Sites 211, 212,213 , and 215 plotted together with the mid-Indian oceanic ridge basalts (M.I.O.R.). The diabase sill, the amphibolites, and the amphibole-bearing basalts of Site 211 fall far above the MacDonald and Katsura (1964) alkali-basalt-tholeiite division line in a field depleted in $\mathrm{SiO}_{2}(<46 \%)$ and enriched in alkalis $\left(\mathrm{Na}_{2} \mathrm{O}+\mathrm{K}_{2} \mathrm{O}>4 \%\right)$ (Figure 5). The basalts found from the Indian Ocean islands and from the M.I.O.R. fall in a field of lower total alkalis and silica content than the rocks from Site 211 (Figures 6, 7). The metabasalts from Site 212 are scattered above the Hawaiian division line in a field enriched in alkalis, mostly $\mathrm{K}_{2} \mathrm{O}(>1)$, and relatively depleted in $\mathrm{SiO}_{2}(42-47 \%)$ with respect to the M.I.O.R. basalts (Figure 5). This discrepancy is partially attributed to weathering and to a late hydrothermal process which has increased the $\mathrm{K}_{2} \mathrm{O} / \mathrm{Na}_{2} \mathrm{O}$ ratio $(>1)$ and redistributed the $\mathrm{SiO}_{2}$ content of the original basalt. Most of the basin floor basalts of Sites 213 and 215 shown in Figure 5 fall within the field of M.I.O.R. tholeiites. Two analyses of basalts which plot outside the field of the M.I.O.R. basalt are abundantly weathered (Figure 5). Figure 6 shows the total alkalis and silica variation of the rocks from the Ninetyeast Ridge (Sites 214 and 216). The basaltic rocks from both sites (214 and 216) plot near and on the Hawaiian division line in a field of low alkalis $\left(\mathrm{Na}_{2} \mathrm{O}+\mathrm{K}_{2} \mathrm{O}<4 \%\right)$ and variable $\mathrm{SiO}_{2}$ contents $(42.50 \%)$. The intermediate types of rocks from Site 214 plotted on the same diagram (Figure 6) fall in a field slightly higher in total alkalis $(>4 \%)$ and higher in silica $(>54 \%)$ than the basaltic rocks from Sites 214 and 216 (Figure 6). 
AMPHIBOLITE SITE 211

- AMPHIBOLE BEARING BASALT SITE 211

(- DIABASE SILL SITE 211

a METABASALt SITE 212

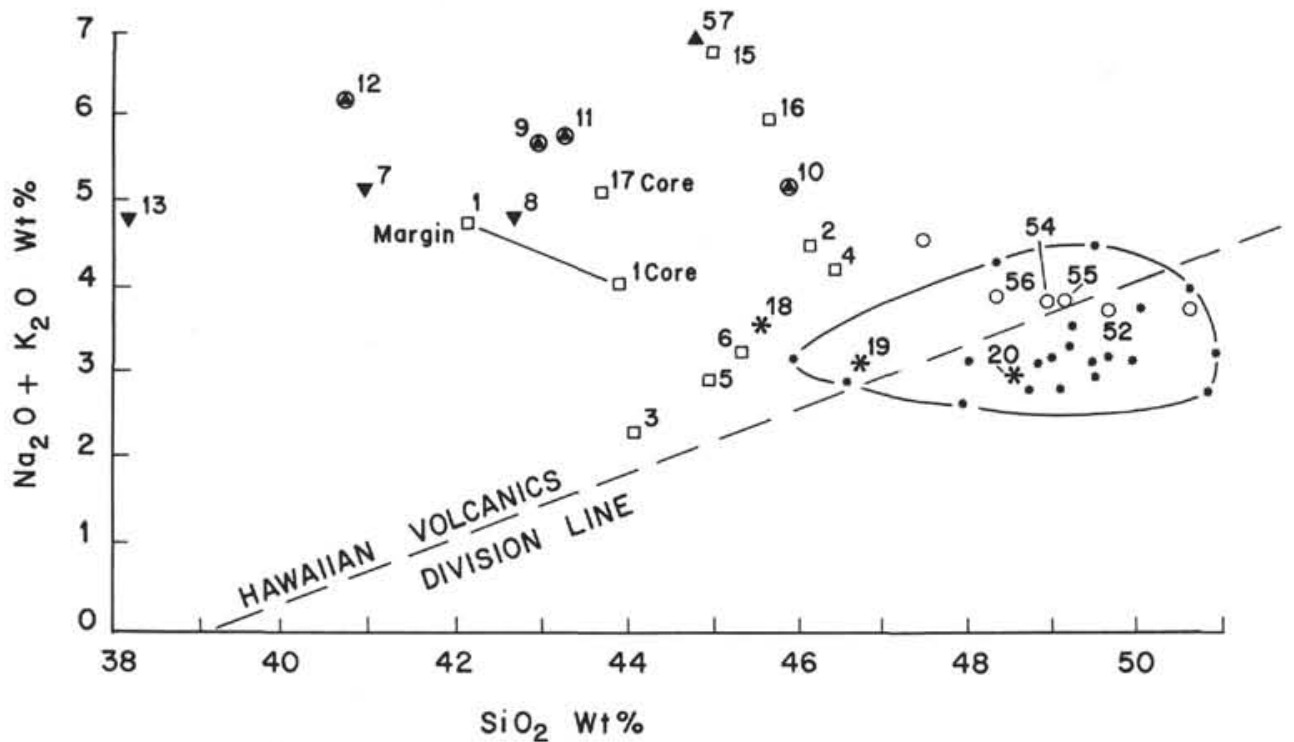

* basalt site 213

- BASALT SITE 215

- MID-INDIAN OCEANIC RIDGE BASALTS

Figure 5. Total alkalis-silica variation diagram of the northeastern Indian Ocean floor rocks compared to the mid-Indian oceanic ridge tholeiites. The numbers associated with each sample indicate the laboratory number.

Many of the basalts from the islands of the Indian Ocean shown on the total alkali-silica variation diagram (Figure 7) are clustered near the Hawaiian division line within a field having a total alkali content between 2 and $4 \%$ and a silica content between 44 and $49 \%$. The differentiated series of these islands show a scattered trend of both alkali enrichment and alkali depletion. The basalts and differentiated series from Reunion Island falling near and on the Hawaiian division line have been classified by Coombs (1963) as mildly alkaline or transitional types between alkali-basalts and tholeiites. The basalts from Ninetyeast Ridge show a similar total alkali-silica variation trend as do the rocks from New Amsterdam and St. Paul islands and the mildly alkaline types from Reunion Island (Figures 6, 7). However, the Ninetyeast Ridge basalts have a lower $\mathrm{K}_{2} \mathrm{O}$ content $(<0.4 \%)$ than those from Reunion, New Amsterdam, and St. Paul islands, and the normative hypersthene and quartz contents of the basalts from Ninetyeast Ridge are similar to those of the islands of New Amsterdam and St. Paul (Table 8). The differentiated rocks from Site 214 also have a lower alkali content than do the benmoreitic rocks of Reunion. These considerations, based on the total alkali and silica contents, suggest that the basalts and the intermediate types of rocks from the Ninetyeast Ridge have a slightly more tholeiitic character than the Reunion Island rocks and are closer in composition to the New Amsterdam and St. Paul islands series.

The A-F-M diagram is another Figure (8) which was useful in comparing the different types of rocks from the Indian Ocean. Figure 8 shows the plot of the diabase sill, the amphibolite, the metabasalt, the differentiated rocks, and basaltic rocks from the drilling sites $(211,212,213$, 214,215 , and 216) together with the average trend of the Indonesian volcanics. Other published data from the M.I.O.R., from the Amirante Ridge, and from some of the Indian Ocean islands are plotted on separate A-F-M diagrams (Figures 9, 10). Figure 8 shows that the amphibolitic rocks and the diabase sill samples from Site 211 plot in a field of a lower $\mathrm{FeO}^{+} / \mathrm{MgO}^{2}$ ratio than other samples from the Ninetyeast Ridge (Sites 214, 216) and than other samples from Site 213. The fresher samples from the diabase sill are in the field of other mid-Indian oceanic ridge basalts while the two samples from the weathered margin which are enriched in potash fall on the average trend of the Indonesian volcanics as do the fresh amphibolites. The freshest specimens show an increase in their total alkali content while their $\mathrm{FeO}^{+} / \mathrm{MgO}$ ratio stays constant (Figure 8). This later observation characterizes a typical calc-alkaline liquid trend of fractionation. The $\mathrm{FeO}^{+} / \mathrm{MgO}$ ratio of the amphibolites from Site 211 is also similar to that of the Christmas Island rocks (Figures 8,10). The basin floor basalts and metabasalts of Sites 212 and 215 have a $\mathrm{FeO}^{+} / \mathrm{MgO}$ ratio similar to other mid-Indian oceanic ridge basalts and spilites (Figures 8,9 ). Samples from Site 213 have a higher $\mathrm{FeO}^{+} / \mathrm{MgO}$ ratio than those from Sites 212 and 215.

The samples from the Ninetyeast Ridge of Sites 214 and 216 show a considerably higher $\mathrm{FeO}^{+} / \mathrm{MgO}$ ratio when

\footnotetext{
${ }^{2}+=$ total $\mathrm{Fe}$ calculated or $\mathrm{FeO}$.
} 


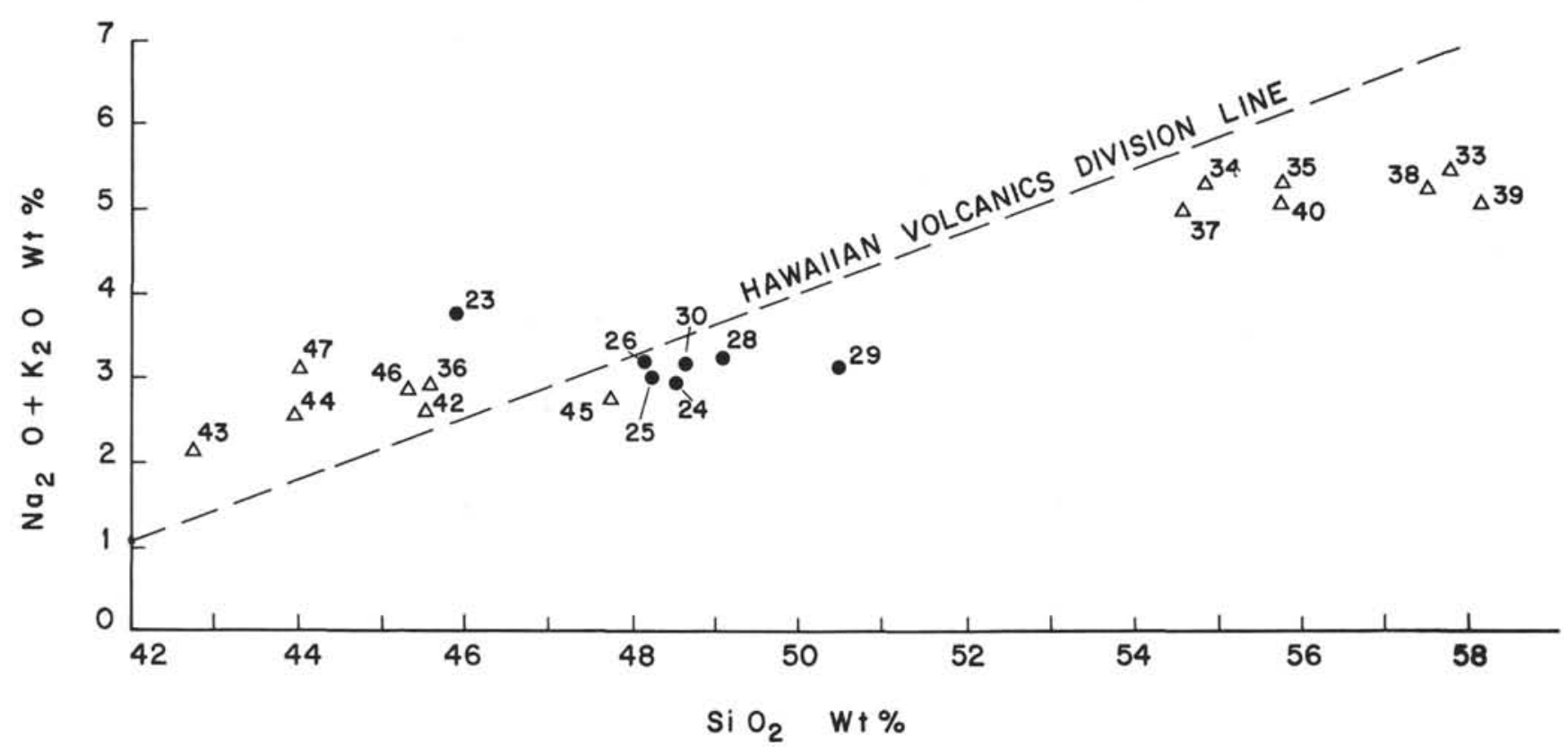

NINETYEAST RIDGE

$\Delta$ Site 214

- Site 216

Figure 6. Total alkalis-silica variation diagram of the samples recovered from the Ninetyeast Ridge. Samples $36.42,43,44$, 45, 46, and 47 are the basaltic rocks from Site 214. Samples 33, 34, 35, 37, 38, 39, and 40 represent the intermediate differentiated rocks from Site 214. Samples 23, 24, 25, 26, 28, 29, and 30 are the basaltic rocks from Site 216.

compared to the basin floor rocks and the mid-Indian oceanic ridge rocks. The basalts from both Sites 214 and 216 are clustered together in a field near the total iron (as $\mathrm{FeO}$ ) corner while the differentiated rocks from Site 214 are clustered in a field which is slightly depleted in total iron (as $\mathrm{FeO}$ ) and enriched in total alkalis (Figure 8). The trend of the $\mathrm{FeO}^{+} / \mathrm{MgO}$ ratio of the rocks from the Ninetyeast Ridge is similar to the trend of the total iron (as $\mathrm{FeO}$ ) content of St. Paul, New Amsterdam and Reunion islands (Figures 8,10 ). The Indonesian volcanics start off with a less pronounced variation of the $\mathrm{FeO}^{+} / \mathrm{MgO}$ ratio than the Ninetyeast rocks, and the trend of iron enrichment is also lower than the one followed by the rocks from the Ninetyeast Ridge (Figure 8). The Ninetyeast Ridge rocks also differ from typical andesites found in island arc formations and continental calc-alkaline provinces by the absence of modal hypersthene, by the normative quartz content which is usually less than $15 \%$, and by the higher $\mathrm{TiO}_{2}$ content $(>1 \%)$. The same rocks also show a distinct enrichment of magnesia and total iron oxides with respect to the calc-alkaline series from the West Indies and from the Indonesian arc. However, the low $\mathrm{K}_{2} \mathrm{O} / \mathrm{Na}_{2} \mathrm{O}$ ratio $(<1)$ is similar to the sodic series of the hawaiite-mugearitebenmoreite suite from Hawaii (MacDonald and Katsura, 1964).

\section{VESICLES AND AMYGDULES}

Vesicles and amygdules $(>0.5 \mathrm{~cm}$ in diameter) have been found in the rocks from Sites 213, 214, and 216. The vesicles and amygdules considered here have an average diameter greater than $0.4 \mathrm{~cm}$ and are of a nearly spherical form homogeneously distributed. Structurally there are two types of vesicle concentration: (1) the vesicles are located either on the top or at the bottom of a flow at contact with a different unit; or (2) the vesicles are concentrated within the flow itself with no sharp vesiculated boundary (e.g., Site 213, Core 19, Section 2 and Site 216, Core 37, Section 3) (Figure 2). The vesicles and amygdules often occur in well-crystallized rocks (Sites 214 and 216) and also in poorly crystallized, scoriaceous rocks (Site 216, Core 37, Section 1 and Core 38, Section 3) (Figure 2). It has been shown (elsewhere, this volume) that a shallow-water environment gave rise to the sediments overlying the igenous rocks of Sites 214 and 216 . Hence, it is probable that some of the vesicularity of these rocks has to be attributed to a low pressure extrusive environment. According to Moore's (1965) study of Hawaiian basalts, the likely depth of extrusion for these rocks is subaerial or under shallow-water conditions; however, the depth at which vesicles form is uncertain and may vary with the gas 


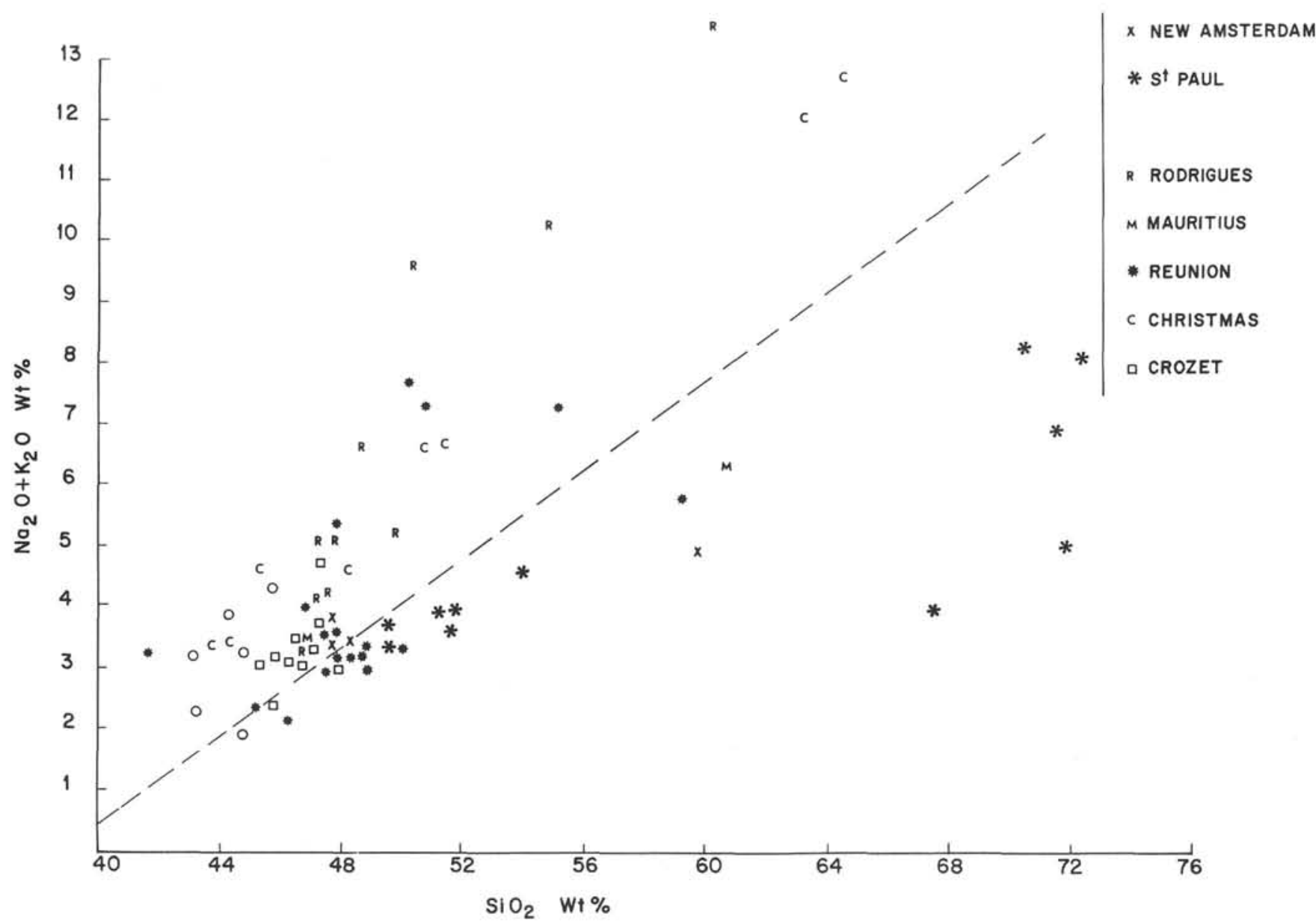

Figure 7. Total alkalis-variation diagram of some differentiated series from the Indian Ocean islands: New Amsterdam, St. Paul (Reinich, 1908), Rodrigues (Upton et al., 1967), Mauritius (Shand, 1932), Reunion (Upton and Wadsworth, 1966; 1967), Christmas (Smith and Mountain, 1925) and Crozet (Gunn et al., 1970).

content, the degree of vesiculation, and the density of the overlying flow (MacDonald, 1963). The occurrence of vesicles which are concentrated in certain zones of the inner portion of a flow (e.g., Site 213, Core 19, Section 2 and Site 216, Core 37, Section 3) could also be due to the independent segregation of gaseous phases from the depth of the extrusion. The pillow-lavas of Site 213 containing large vesicles (up to $1 \mathrm{~cm}$ in diameter) are covered by a deep-water sediment. In this instance, there is no indication that the pillow-lava basalts containing the large vesicles were extruded at shallow depths.

\section{SUMMARY AND CONCLUSIONS}

The intrusive and extrusive rocks from Leg 22 of the Glomar Challenger in the Indian Ocean are divided into the following seven types according to their physical and textural appearances, their mineral contents and their chemistry. They are: (a) the diabase of Site 211, (b) the amphibolite of Site 211, (c) the amphibolite-bearing basalt of Site 211, (d) the pillow-lava metabasalt of Site 212, (e) the basin floor pillow-lava basalts of Sites 213 and 215,

(f) the pyroxene enriched basalts of Sites 214 and 216, and

(g) the differentiated intermediate rocks of Site 214.
The diabase of Site 211 represents an intrusive body within a sedimentary unit. The amphibole-bearing basalts are considered to be extrusive and are interlayered with an amphibolite flow. The contacts between the amphibolite and the amphibole-bearing basalts are sharp and altered. Both contain similar types of hornblende and mica. The presence of partially replaced pyroxene and the occurrence of calcite veins containing amphiboles indicate that the amphibole-bearing basalts were hydrothermally altered by the amphibolite flows themselves.

Site 211 is thought to be the first occurrence of amphibolitic rocks encountered on the floor of the Indian Ocean. In the Atlantic, amphibolitic rocks were found (Kay et al., 1970; Bonatti et al., 1971) on adjacent fracture zones of the Mid-Atlantic Ridge Rift Valley at $31^{\circ} \mathrm{N}$ and in the equatorial region. Other amphibolites have been described from the Palmer Ridge in the North Atlantic Ocean (Cann, 1971). Amphibolites of erratic origin were also mentioned by Muir et al. (1964) as occurring in the North Atlantic. The amphibolitic rocks from the Atlantic ocean floor showing shearing and cataclastic textures are commonly observed in samples from fracture zone areas, while less shearing and a preserved igneous texture characterize the rocks from the Palmer Ridge (Cann, 1971). 


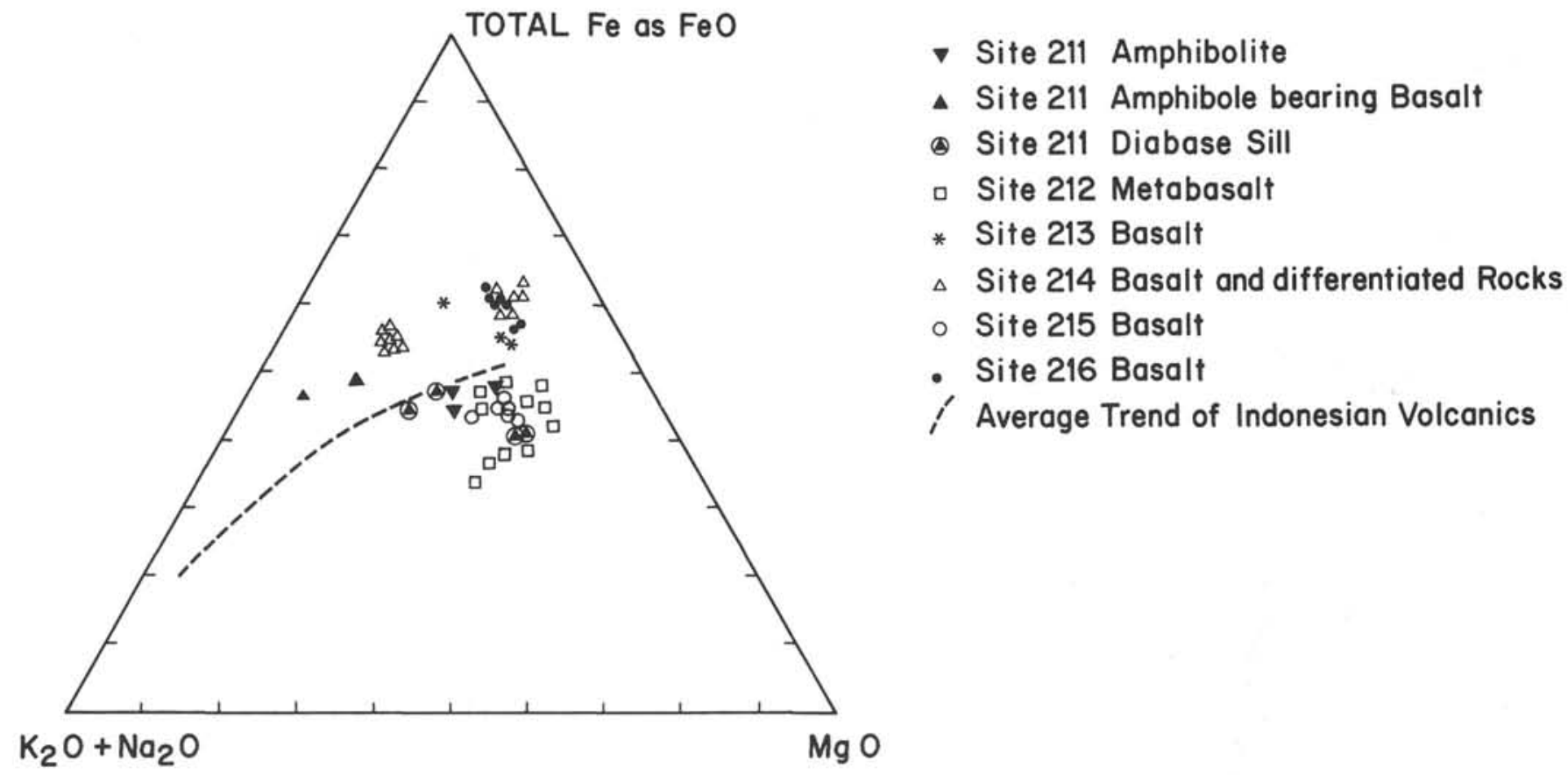

Figure 8. A-F-M Ternary diagram of the northern Indian Ocean rocks recovered during Leg 22 of the Glomar Challenger. The average calc-alkaline trend of the Indonesian volcanics (Rittman, 1953; Tazieff et al., 1966) is also shown.

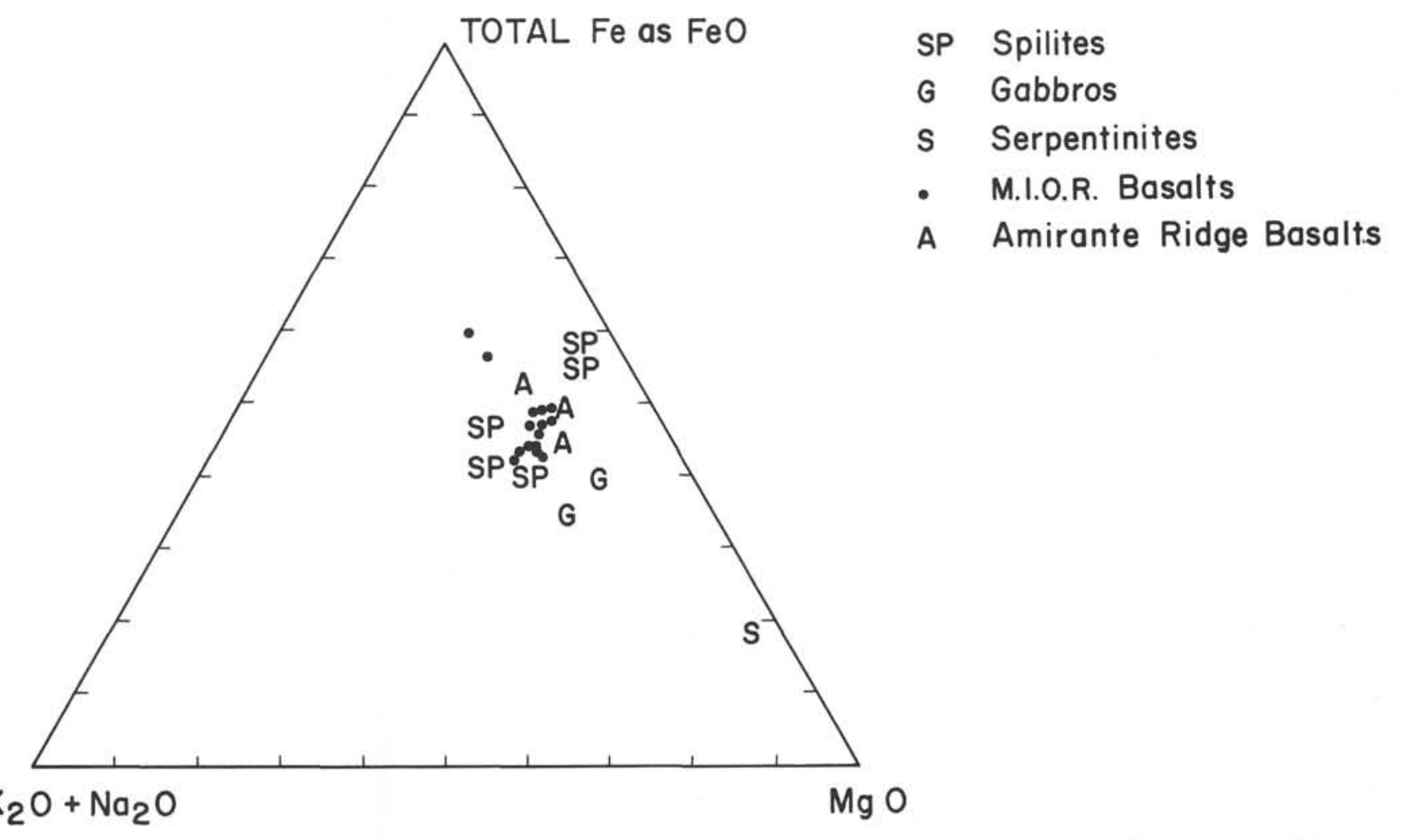

Figure 9. A-F-M Ternary diagram of the samples recovered on the mid-Indian oceanic ridge and from associated fracture zones. Notice that the Amirante Ridge basalts plot in the field of the Spreading ridge basalts. The references are the same as in Figure 3. 


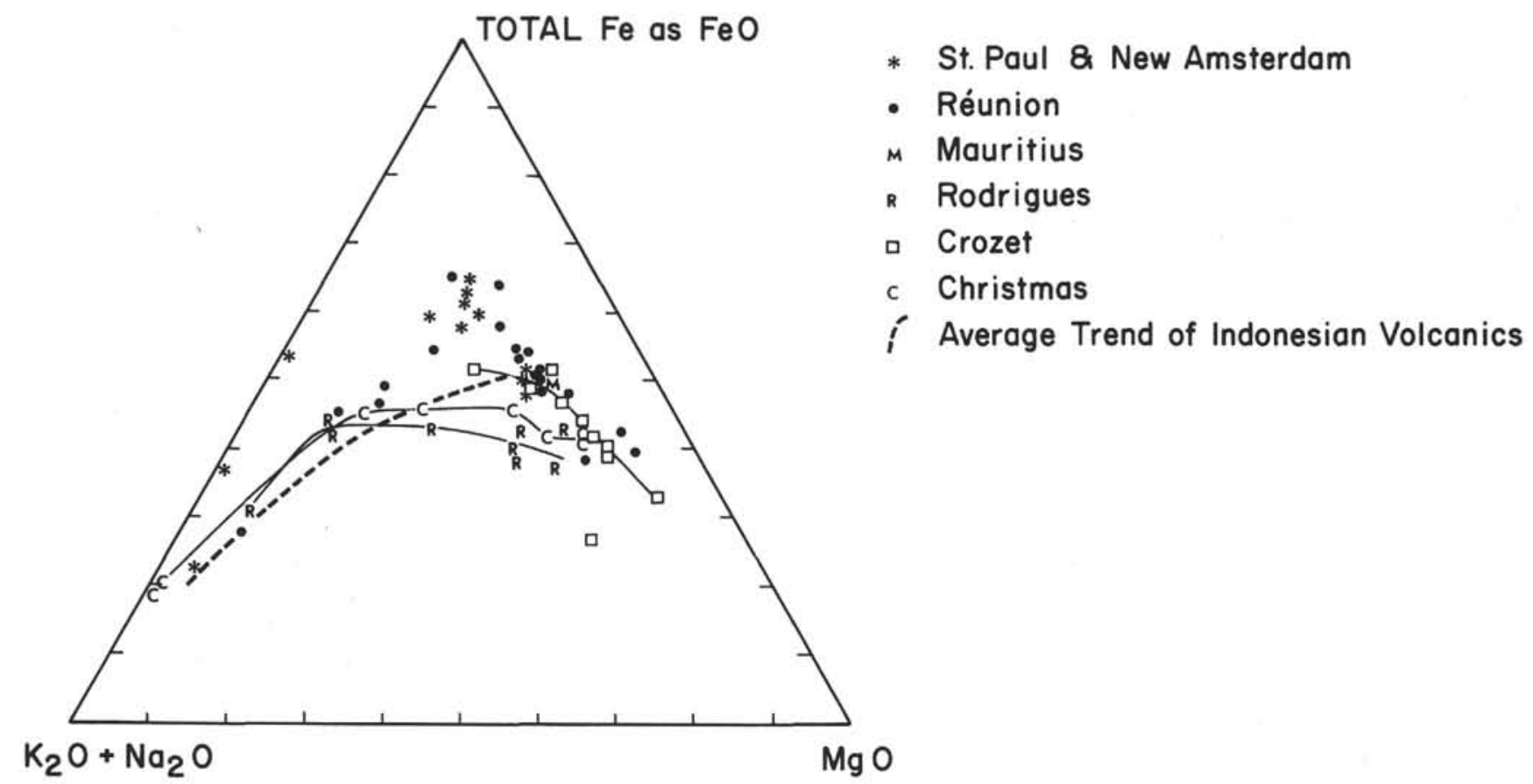

Figure 10. A-F-M Ternary diagram of the Indian Ocean islands. The references are the same as in Figure 7.

Metamorphism seems to be the main process giving rise to amphibolitic rocks in the Atlantic Ocean. The amphibolites from Site 211 are not similar in appearance to the foliated amphibolite from continental regions, nor are they comparable to other metamorphic amphibolites showing the primary mineral replacement of those found in the Atlantic Ocean. On the contrary, the physical aspect of the amphiboles (i.e., radial growth, felted aggregates), the presence of glass, the lack of foliation, and the absence of any reaction effect such as the replacement of other minerals by amphiboles seem to point out a magmatic origin for these amphibolites.

Both types of rock, the diabase and the amphibolite, lack normative quartz and have normative nepheline, which suggests the undersaturated nature of the parental magma. In addition, the presence of mica appears to be restricted to rocks having alkali-basalt affinities (Yoder and Tilley, 1962). Experimental work (Yoder and Tilley, 1962; Green and Ringwood, 1968) has shown that under wet conditions $\left(>2 \mathrm{~Kb}, \mathrm{H}_{2} \mathrm{O}\right.$ pressure) amphibole will be the main phase crystallizing from a basaltic magma. It is evident that the diabase sill and the amphibolites all contain mica, amphibole, and other hydrated phyllosilicates. Also, the water content of these rocks is relatively high. The origin of water, critical for the formation of amphiboles, cannot be attributed to seawater contamination since these rocks do not show traces of excessive weathering. Hence, it is likely that the rocks from Site 211 were formed from a hydrous melt having an undersaturated character. The nature of this melt could be due to the melting of either a water-rich alkali basalt or an amphibolite.

The metabasalts of Site 212, from the Wharton Basin, consist of a succession of altered pillow-lavas. The alteration product has been attributed to both weathering by seawater and to a hydrothermal process which is responsible for the presence of chlorite-quartz-pumpellyite assemblages. It is not excluded that hydrous solutions generated deep in the oceanic crust could provide certain conditions appropriate for the precipitation of pumpellyitequartz-chlorite assemblages. It is hard to reconcile the idea of low grade metamorphism, as suggested by the presence of chlorite and pumpellyite, with the tectonic setting of the area. It has been shown that the pumpellyite-prehnitequartz facies is stable above about $200^{\circ} \mathrm{C}$ and pressure higher than $1 \mathrm{~kb}$ (Coombs et al., 1960). The sediment cover plus the water column above these metabasalts does not even come close to the above pressure-temperature conditions. The superimposition of the two processes, weathering and late hydrothermal alteration, makes it difficult to speculate on the origin of the metabasalts of Site 212.

The basin floor basalts of Sites 213 and 215 represent a series of pillow-lavas lying on top of each other and sometimes having a thin indurated sediment pocket between individual pillow-lavas. The pillow-lava units of Sites 213 and 215 are similar in composition to other rocks of mid-oceanic spreading ridges. However, the $\mathrm{K}_{2} \mathrm{O}$ content of these rocks is generally higher than the average potash content of the M.I.O.R. basalts. This discrepancy could be due to weathering.

Ninetyeast Ridge samples (Sites 214 and 216) consist of basalts enriched in clinopyroxene (214 and 216) and intermediate differentiated rocks (214). These rocks differ from calc-alkaline suites by their higher $\mathrm{TiO}_{2}$ content and higher $\mathrm{FeO} / \mathrm{MgO}$ ratio. Since the differentiated rocks from Site 214 are not similar to the calc-alkaline suites found in continental regions or in island arcs, the name oceanic andesite is a more appropriate term for this type of rock. 
These rocks differ from the other basin floor basalts (Sites 213 and 215) and from the M.I.O.R. basalts in their appearances and composition. There is a lack of the thin chilled glassy margin which characterizes pillow-lavas in general They have a thicker ( $>6 \mathrm{~m}$ thick) individual flow than known oceanic pillow-lavas so they cannot really be considered as pillow-lavas. They have a high ferromagnesian/plagioclase ratio which reflects their high $\mathrm{Fe}_{2} \mathrm{O}_{3}+$ $\mathrm{FeO} / \mathrm{MgO}$ ratio. A similar enrichment in iron oxide content is due to differentiation by crystal fractionation as suggested by the cumulate appearance of the clinopyroxene. It is likely that such crystal fractionation could have taken place in a "magmatic chamber" before extrusion of the flow on the surface. This is in agreement with the absence of crystal fractionation effects within each flow. The sequence of the magmatic events agrees with the occurrence of the differentiated rocks which correspond to the last stage of magmatism. The basalts and the differentiated flow are separated from each other (e.g., Site 214) by thin pyroclastic layers. The layers are believed to represent the debris of basaltic rock having a composition similar to the underlying basalt (Site 214, Core 52, Section 1, and Core 53, Section 2; and Site 216, Core 36, Section 4, Figure 2). The presence of the debris could be due to surface degradation of the basaltic flow or could represent volcanic ejecta thrown out during the last stage of volcanism.

The principal petrological conclusions of this study are summarized as follows:

1) The diabase sill and the amphibolite from Site 211 are undersaturated rocks. These rocks have derived from the melting of either a water-rich alkali basalt or an amphibolite.

2) The amphibolites from Site 211 are igneous in origin.

3) The metabasalts of Site 212 are altered pillow-lavas. The alteration product is attributed to both weathering by seawater and a hydrothermal process rather than to burial metamorphism.

4) The weathered basalts from Sites 213 and 215 are pillow-lava sequences with a $\mathrm{K}_{2} \mathrm{O}$ content higher than the average potash content of the M.I.O.R. basalts. This discrepancy is attributed to seawater weathering.

5) The basaltic rocks from Sites 214 and 216 on the Ninetyeast Ridge are similar to each other. These basalts have a higher $\mathrm{FeO} / \mathrm{MgO}$ ratio than the M.I.O.R. basalts as well as a higher $\mathrm{TiO}_{2}$ content $(>2 \%)$, a higher $\mathrm{K}_{2} \mathrm{O}$ content $(0.18-0.90 \%)$, and a higher total iron content $(>11 \%)$. No pillowed structure could be recognized.

6) The basalts from the Ninetyeast Ridge are similar in composition to those from St. Paul and New Amsterdam islands.

7) Differentiated rocks having compositions similar to those from St. Paul and New Amsterdam were found at Site 214 on the Ninetyeast Ridge. These rocks have a high $\mathrm{SiO}_{2}$ content $(54-58 \%)$, a high $\mathrm{TiO}_{2}$ content $(>2 \%)$, and a total alkali content less than $5 \%$.

8) Zones of mineralization with a concentration of native copper and iron sulfate minerals are found at Sites 214 and 216 from the Ninetyeast Ridge and in the diabase sill of Site 211 on the northeastern edge of the Wharton Basin.
9) The rocks from the Ninetyeast ridge are similar to other aseismic ridge volcanics. The rocks from aseismic ridges are different from normal mid-oceanic ridge basalts.

\section{ACKNOWLEDGMENTS}

The author is indebted to the members of the scientific party, the drilling personnel, the Captain and crew of the Glomar Challenger whose efforts all contributed to the recovery of basement rocks. Dr. J. Morgan read the manuscript and gave helpful criticisms.

\section{REFERENCES}

Aumento, F., Loncarevic, B. D., and Ross, D. I., 1971. Hudson Geotraverse: Geology of the Mid-Atlantic Ridge at $45^{\circ} \mathrm{N}$ : Phil. Trans. Roy. Soc. London A, v. 268, p. 623-650.

Belousov, I. M., Zatonskii, L. K., Kanaev, V. F., and Marova, H. A., 1962. Bathymetric map of the Indian Ocean from the Institute of Oceanology, USSR.

Bezrukov, P. L., Krylov, A. Ya, and Chernysheva, V. I., 1966. Petrography and absolute age of basalts from the floor of the Indian Ocean: Oceanology, v. 6, p. 210-214.

Bonatti, E., Honnorez, J., and Ferrara, G., 1971. Peridotite-gabbro-basalt complex from the equatorial Mid-Atlantic Ridge: Phil. Trans. Roy. Soc. London, A, v. 268 , p. $385-402$.

Bunce, E. T., Bowin, C. O., and Chase, R. L., 1966. Preliminary results of the 1964 Cruise of R.V. Chain to the Indian Ocean: Phil. Trans. Royal Soc. London, A, v. 259 , p. 218-226.

Cann, J. R., 1969. Spilites from the Carlsberg Ridge, Indian Ocean: J. Petrol., v. 10, p. 1-19.

1971. Petrology of basement rocks from Palmer Ridge, NE Atlantic: Phil. Trans. Roy. Soc. London A, v. 268 , p. 607-617.

Cann, J. R., and Vine, F. J., 1966. An area on the crest of the Carlsberg Ridge. Petrology and magnetic survey: Phil. Trans. Royal, Soc. London, A, v. 259, p. 198-217.

Chernysheva, V. T. and Bezrukov, P. L., 1966. Serpentinite from the crest of the Indo-Arabian Ridge: Dokl., Acad. Sci., v. 166, p. 207-210.

Coombs, D. S., Ellis, A. F., Fyfe, W. S., and Taylor, A. M., 1960. Lower grade mineral facies in New Zealand: Inter. Geol. Congr., 21st, Copenhagen, Repts., pt. 13, p. 339-351.

Engel, G. C., and Fisher, R. L., 1969. Lherzolite, anorthosite, gabbro and basalt dredged from the mid-Indian Ocean ridge: Science, v. 166, p. 1136-1141

Engel, G. C., Fisher, R. L., and Engel, A. E. J., 1965. Igneous rocks of the Indian Ocean: Science, v. 150 (3696), p. 605-610.

Fisher, R. L., Engel, C. G., and Hilde, T. W. C., 1968. Basalts dredged from the Amirante Ridge, western Indian Ocean: Deep-Sea Res., v. 15, p. 521-534.

Gladkikh, V. S. and Chernysheva, V. I., 1966. Rare Elements in suboceanic mafic extrusives: Geochem. Intern., v. 3, p. 786-789.

Green, T. H. and Ringwood, A. E., 1968. Genesis of the calc-alkaline igneous rock suite: Contrib. Min. Petrol., v. 18 , p. $105-162$.

Gunn, B. M., Coy-Yill, R., and Watkins, N. D., 1970. Geochemistry of an oceanite-ankarimite-basalt series 


\section{R. HEKINIAN}

from East Island, Crozet: Contrib. Min. Petrol., v. 28, p. 319-339.

Heezen, B. C. and Nafe, J. E., 1964. Vema Trench: western Indian Ocean: Deep-Sea Res., v. 118, p. 79-84.

Hekinian, R., 1968. Rocks from the mid oceanic ridge in the Indian Ocean: Deep-Sea Res., v. 15, p. 195-213. 1970. Gabbro and pyroxenite from a deep-sea core in the Indian Ocean: Marine Geol., v. 9, p. 287-294.

Kay, R., Hubbard, N. J., and Gast, P. W., 1970. Chemical characteristics and origin of oceanic ridge volcanic rocks: J. Geophys. Res., v. 75 (8), p. 1585-1613.

Korzhinskiy, D. S., 1962. Spilites and the transvaporization hypothesis in the light of new oceanological and volcanological data: Izv., Acad. Sci. USSR, Ser. Geol., v. 9, p. 13-19.

Laughton, A. S., 1966. The Gulf of Aden: Trans. Royal, Soc. London, A, v. 259, 150 p.

MacDonald, G. A., 1963. Physical properties of erupting Hawaiian magmas: Geol. Soc. Am. Bull., v. 74, p. 1071.

MacDonald, G. A. and Katsura, T., 1964. Chemical composition of Hawaiian lavas: J. Petrol., v. 5, p. 82-133.

Matthews, D. H., 1966. The Owen fracture zone and the northern end of the Carlsberg Ridge: Phil. Trans. Royal, Soc. London, A, v. 259, p. 172-186.

Melson, C. W. and Van Andel, T. H., 1966. Metamorphism in the mid-Atlantic Ridge, $22^{\circ} \mathrm{N}$ latitude. Marine Geol., v. 4 , p. $165-186$.

Moore, J. G., 1965. Petrology of deep-sea basalt near Hawaii: Am. J. Sci. v. 263, p. 40.

Muir, J. D., Tilley, C. E., and Scoon, J. H., 1964. Basalts from the northern part of the rift zone of the Mid-Atlantic Ridge: J. Petrol., v. 5. (3), p. 409434.

Reinisch, R., 1908. Petrographie: II, Gesteine von der Bouvet-Insel, von Kerguelen, St. Paul und Nev-Amsterdam: In Wissenschaftliche Ergebnisse Der Deutschen Tilfsee Expedition 1898-1899, v. 10, p. 47-75.
Rittman, A., 1953. Magmatic character and tectonic position of the Indonesian volcanoes: Vull. Volcanol., Ser. 2. 14.

Schilling, J., 1969. Origin of the Red Sea floor: Rare earth evidence: Science, v. 165, p. 1357-1360.

Shand, S. J., 1932. The lavas of Mauritius: Geol. Soc. London Quart. J., v. 89, p. 1-13.

Smith, W. Campbell and Mountain, E. D., 1925. Volcanic rocks of Christmas Island (Indian Ocean): Geol. Soc. Quart. J., v. 82, p. 44-66.

Tazieff, H., Marinelli, G., and Gorshkov, G.S., 1966. Indonesian volcanological Mission (November, 1964 to January 1965): Unesco, Paris.

Udintsev, G. B. and Chernysheva, V. I., 1965. Rock samples from the upper mantle of the Indian Ocean rift zone: Dok1., Akad. Nauk, USSR, Geol., v. 165, p. 85-88.

Upton, B. G. and Wadsworth, W. J., 1966. The basalts of Reunion Island, Indian Ocean: Bull. Volcanol., v. 29, p. 7-24.

1967. The complex basalt-Mugearite Sill in Piton des Neiges volcano. Reunion: Am. Mineralogist, v. 52, p. 1475-1492.

Upton, B. G., Wadsworth, W. J., and Newman, T. C., 1967. The petrology of Rodriguez Island, Indian Ocean: Geol. Soc. Am. Bull., v. 78, p. 1495-1506.

Winkler, H. G. F., 1967. The Petrogenesis of metamorphic rocks: New York (Spring-Verlag), 237 p.

Wiseman, J. D. H. and Poole, J. H. J., 1937. Geological and mineralogical investigations of basalt from the Carlsberg Ridges, Report of J. Murray Expedition 1933-1934: British Museum of Nat. History, v. 3, No. 1, p. 1-28.

Wiseman, J. D. H. and Sewell, R. B. S., 1937. The floor of the Arabian Sea: Geol. Mag., v. 74, p. 219-230.

Yoder, R. H. and Tilley, L. E., 1962. Origin of basaltic magmas: An experimental study of natural and synthetic rock system: J. Petrol., v. 3, p. 342-532. 



\section{PLATE 1}

Figure 1 Photograph of a contact zone between the amphibolite (dark area) and the amphibole-bearing basalt (light area) of Site 211, Core 15, Section 2, 81-89 cm. Notice the rounded patches which become larger toward the basaltic zone.

Figure 2 Photograph of a contact zone between a limestone and a glassy chilled margin of a pillow-lava from Site 215 , Core 18 , Section $1,68-73 \mathrm{~cm}$. The glassy margin is surrounded by a thin palagonite rim. Small amounts of quartz (QT) occur between the palagonite and the limestone. The limestone was found trapped between the chilled margin of two pillow-lavas. 


\section{PLATE 1}
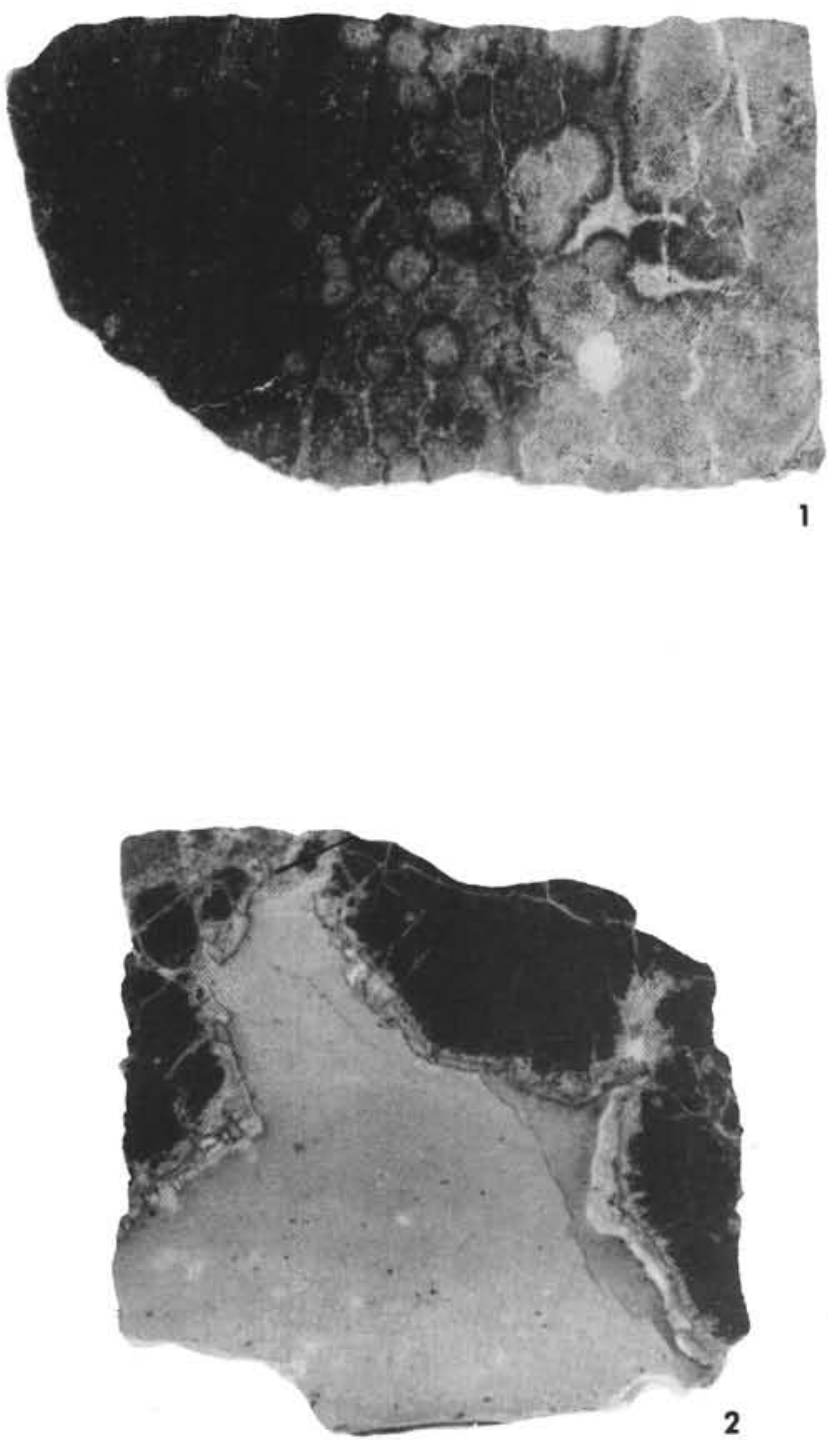


\section{PLATE 2}

Figure 1

Figure 2

Figure 3

Figure 4

Figure 5

Figure 6

Figure 7

Figure 10
Photomicrograph of an amphibolite from Site 211, Core 15, Section 1, 130-134 $\mathrm{cm}$. Notice the radiating arrangement of the arborescent oxyhornblende (XHNB). Common hornblende (HNB) and mica occur.

Photomicrograph of an amphibole-bearing basalt from Site 211, Core 15, Section 3, 67-70 cm. Variolitic arrangement of plagioclase laths occur (Nicols at $30^{\circ}$ ).

Photomicrograph of a metabasalt from Site 212, Core 39 , Section 3, 67-73 cm, showing a plagioclase phenocryst altered into chlorite. Notice the thin rims of sodic plagioclase around the edges of the phenocryst.

Photomicrograph of a basalt from Site 213, Core 18, Section 1, 144-150 cm showing phenocrysts of fresh plagioclase set in a matrix of plagioclase associated with small rods of clinopyroxene.

Photomicrograph of a basalt from Site 215, Core 19, Section 1, $87-93 \mathrm{~cm}$ showing elongated rods of clinopyroxene intimately associated with plagioclase laths.

Photomicrograph of a pyroxene basalt from Site 216, Core 37, Section 4, $120 \mathrm{~cm}$ showing cumulate granules of clinopyroxene and plagioclase laths.

Photomicrograph of an intermediate differentiated rock from Site 214, Core 48, Section 1, 125-133. Sodic plagioclase laths showing fluidal texture are set in a glassy matrix. Notice the interpretation twins of a feldspar in the lower half of the photograph.

Photomicrograph of a vein of vermiculite-smectite mixed layer material Site 214, Core 53, Section 1, $30-35 \mathrm{~cm}$ showing radiating arrangement. This vein occurs in a basalt flow.

Photomicrograph of an aphanitic basalt flow from Site 214, Core 53, Section 1, 30-35 cm showing chloritized plagioclase laths and granules of clinopyroxene. A large clinopyroxene crystal occurs at the center of the photograph (Nicols at $40^{\circ}$ ).

Photomicrograph of a phanetitic holocrystalline vesicular basalt from Site 214, Core 54, Section 1, $93.94 \mathrm{~cm}$ showing fresh plagioclase laths and anhedral clinopyroxene (Nicols at $40^{\circ}$ ). 


\section{PLATE 2}
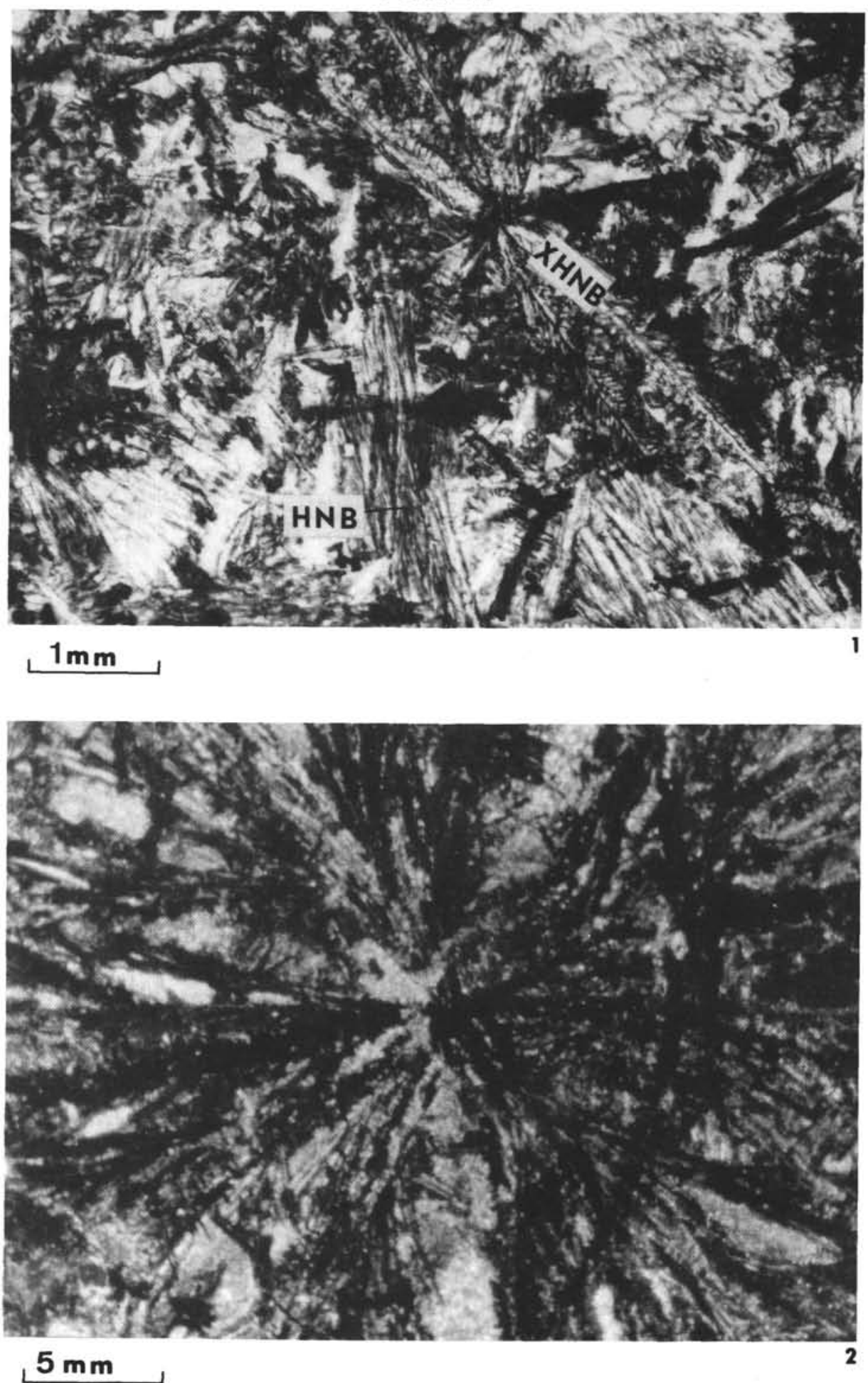
PLATE 2 Cont.
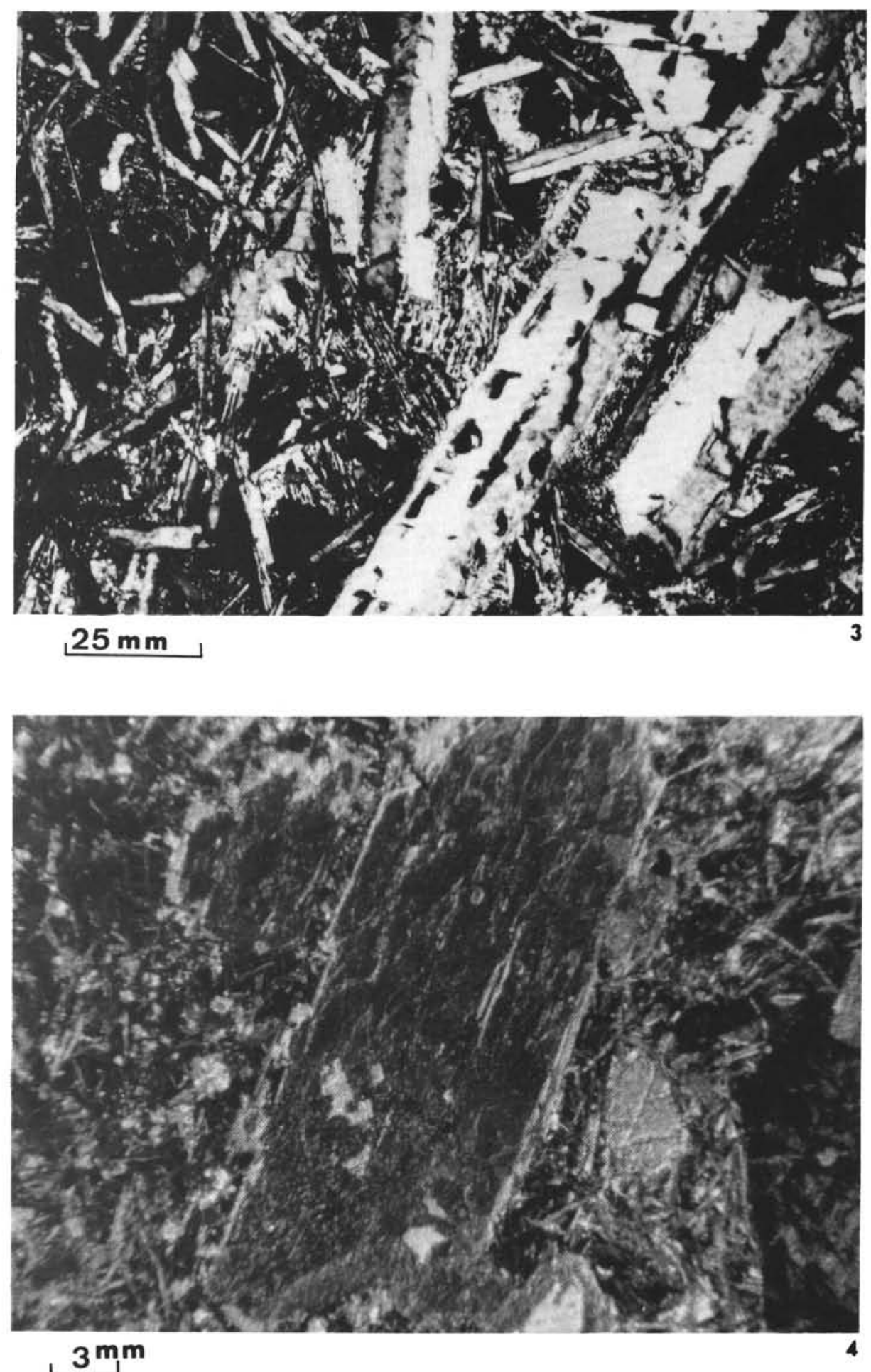
PLATE 2 Cont.
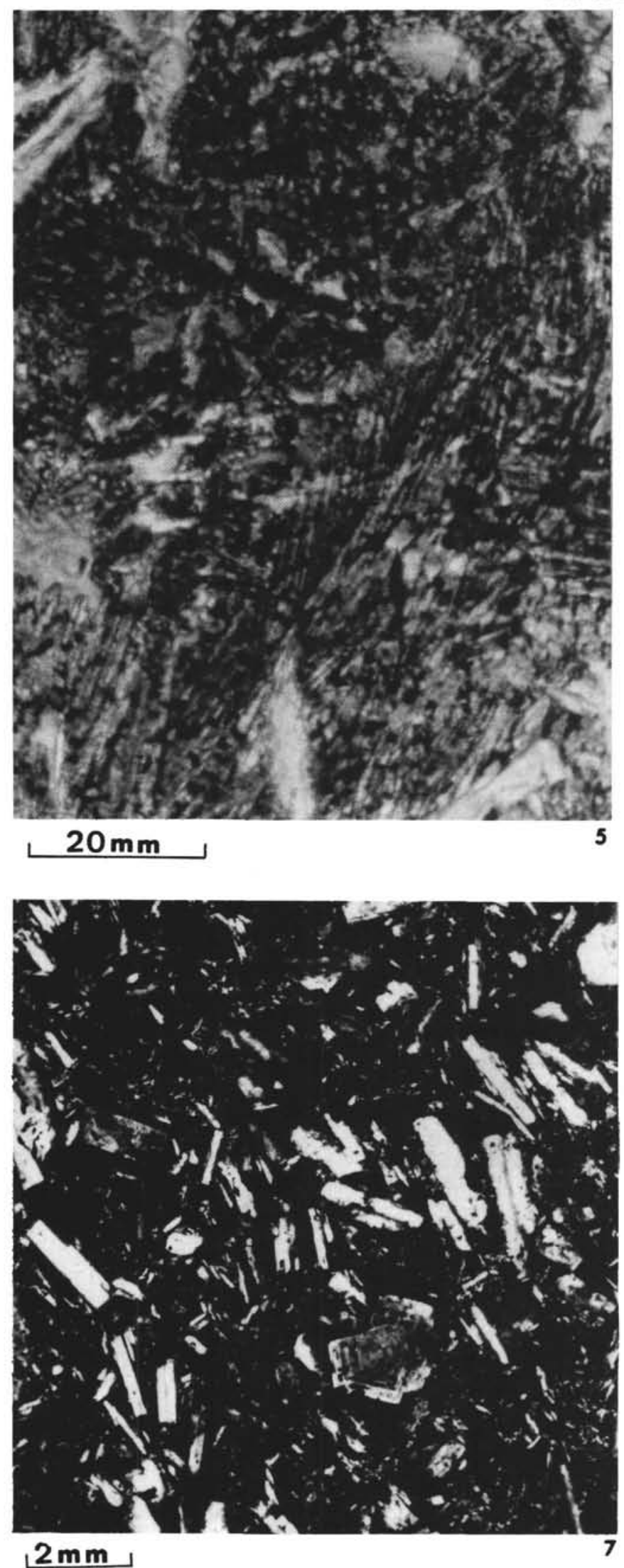
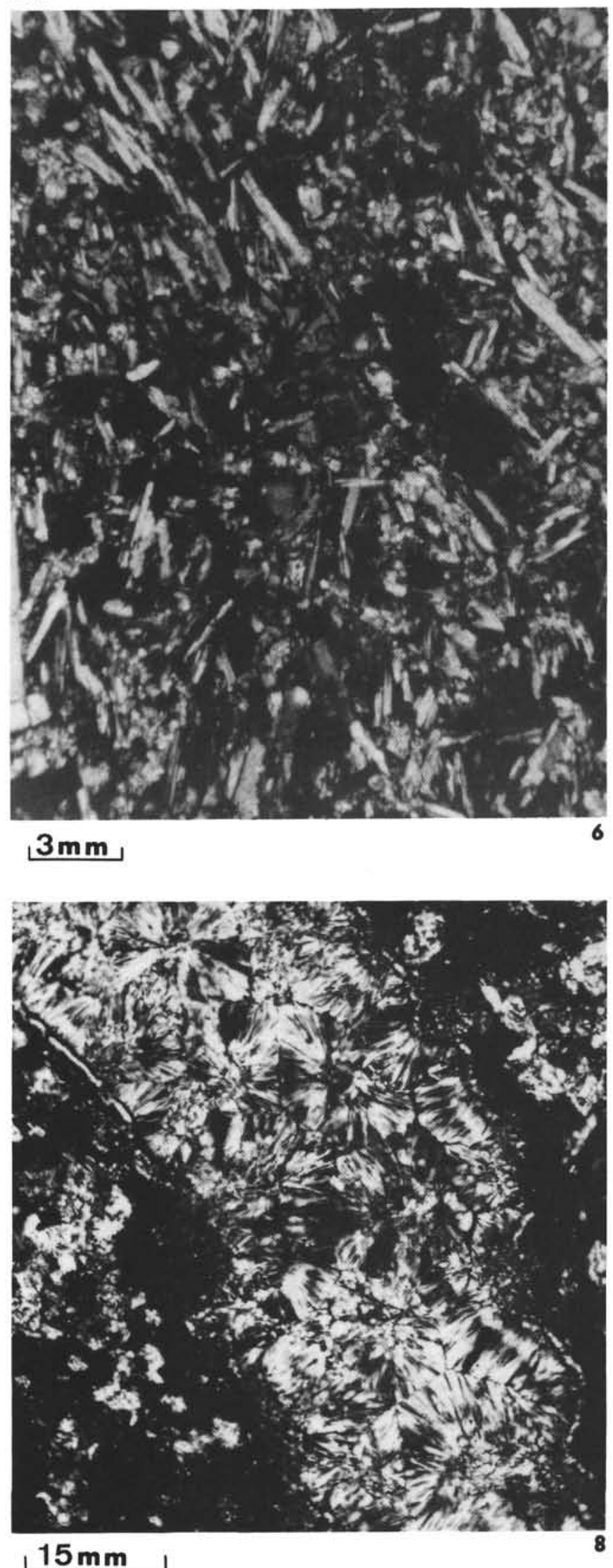
PLATE 2 Cont.
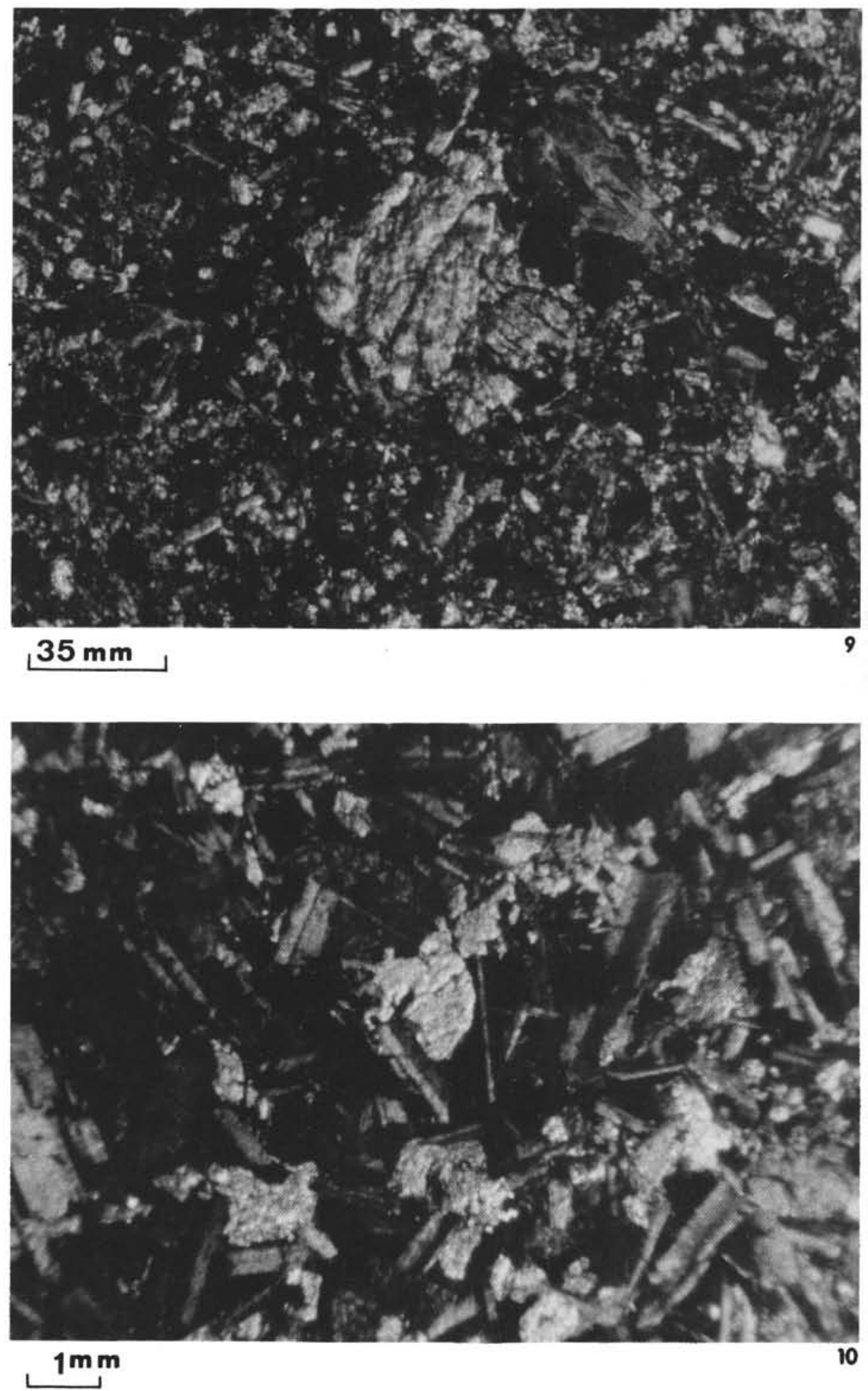



\section{PLATE 3}

Figure 1 Photograph of contact zone between two pillow-lavas of metabasalt at Site 212, Core 39, Section 3, 0-14 $\mathrm{cm}$. The chilled margin is less than $1 \mathrm{~cm}$ thick and is almost completely chloritized (CHL). Relics of black basaltic glass (BG) occur. Also notice the veinlets of quartz (QT), and calcite (C).

Figure 2 Photograph of a carbonate rock (limestone) containing angular fragments of chloritized rock (CHL) and an aphanitic metabasalt (MTB). A vein of quartz (QT) occurs. The limestone is found at the contact between the sediment and the rock unit of Site 212, Core 39, Section 1, 138-144 cm. 


\section{PLATE 3}
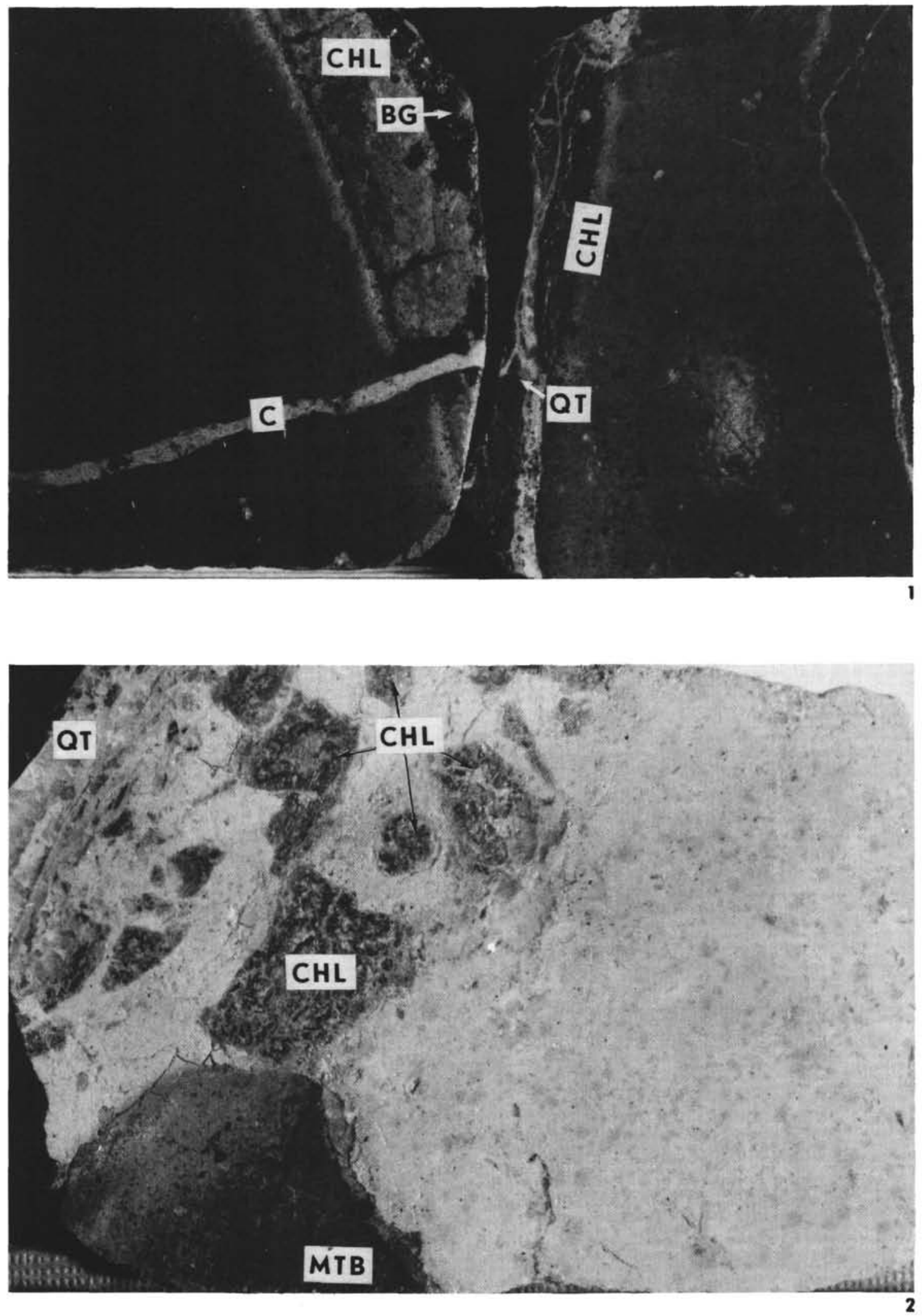